\title{
Bioactive Sphingolipids in Response to Chemotherapy: A Scope on Leukemias
}

\author{
Huseyin Atakan Ekiz ${ }^{1}$ and Yusuf Baran ${ }^{2, *}$
} ${ }^{1}$ Department of Oncological Sciences, University of Utah, Salt Lake City, UT 84112, USA; ${ }^{2}$ İmir Institute of Technology, Department
of Molecular Biology and Genetics, Urla, İzmir 35430, Turkey

\begin{abstract}
Sphingolipids are major constituents of the cells with emerging roles in the regulation of cellular processes. Deregulation of sphingolipid metabolism is reflected as various pathophysiological conditions including metabolic disorders and several forms of cancer. Ceramides, ceramide-1-phosphate (C1P), glucosyl ceramide (GluCer), sphingosine and sphingosine-1-phosphate (S1P) are among the bioactive sphingolipid species that have important roles in the regulation of cell death, survival and chemotherapeutic resistance. Some of those species are known to accumulate in the cells upon chemotherapy while some others are known to exhibit an opposite pattern. Even though the length of fatty acid chain has a deterministic effect, in general, upregulation of ceramides and sphingosine is known to induce apoptosis. However, S1P, C1P and GluCer are proliferative for cells and they are involved in the development of chemoresistance. Therefore, sphingolipid metabolism appears as a good target for the development of novel therapeutics or supportive interventions to increase the effectiveness of the chemotherapeutic drugs currently in hand. Some approaches involve manipulation of the synthesis pathways yielding the increased production of apoptotic sphingolipids while the proliferative ones are suppressed. Some others are trying to take advantage of cytotoxic sphingolipids like short chain ceramide analogs by directly delivering them to the malignant cells as a distinct chemotherapeutic intervention. Numerous studies in the literature show the feasibility of those approaches especially in acute and chronic leukemias. This review compiles the current knowledge about sphingolipids and their roles in chemotherapeutic response with the particular attention to leukemias.
\end{abstract}

Keywords: Ceramide, ceramide-1-phosphate, chemotherapeutic response, dihydroceramide, glucosylceramide, leukemia, sphingosine, sphingosine-1-phosphate.

\section{INTRODUCTION}

Sphingolipids form a major class of lipids found within the eukaryotic membranes and an unusual class of bacterial genus called Sphingobacteria. General structure of sphingolipids contains a long-chain sphingosine base and an amide-linked fatty acid chain. These molecules have amphiphatic structures having polar and nonpolar parts like phospholipids. Various polar head groups and differing lengths of fatty acid chain produce a wide range of sphingolipids and give different characteristics to them. Following their discovery in late 1800 s, versatile nature of sphingolipids appeared enigmatic to scientific community and for a long time, they were thought to be important solely for structural purposes in cells. Last decades have shown that they are not simple cellular building blocks; instead they are involved in several other processes including but not limited to cell cycle control, apoptosis and differentiation [1-3]. Sphingolipids are involved in the regulation of essential cellular processes by participating to signal transduction pathways as secondary messengers.

Studies pointing out the roles of sphingolipids in pathophysiology of various diseases including cancer and metabolic disorders have increased the attention to lipid research lately and therapeutic interventions are started to incorporate approaches targeting sphingolipid synthesis pathways. By means of those efforts, numerous sphingolipid species with promising therapeutic importance are identified by manipulating their cellular levels. Ceramide (Cer), ceramide-1-phosphate (C1P), glucosylceramide (GluCer), dihydroceramide (dhCer), sphingosine (Sph), and sphingosine-1-phosphate (S1P) are among those sphingolipid species that have important regulative roles in cells (for their chemical structures please see Fig. 1). Some of those species play opposing roles while some others are working in concert for the similar outcome; and cellular fate is determined by their interactions and ratios in the cell [4-6].

This review attempts to provide an overview of what is known for particular roles of such sphingolipids, and their implications in

\footnotetext{
*Address correspondence to this author at the Izmir Institute of Technology, Department of Molecular Biology and Genetics; Urla/Izmir/Turkey; Tel: + 90232 7507515; Fax: + 90232 7507509;

E-mail: yusufbaran@iyte.edu.tr
}

cancer area. Roles of sphingolipids will be examined in the perspective of chemotherapeutic response with the emphasis on targeting these mechanisms for the treatment of leukemias. Towards the end, possibility of targeting sphingolipid metabolism as an alternative or a supportive therapeutic intervention will be discussed.

\section{METABOLISM OF SPHINGOLIPIDS}

There are many inter-conversions among different sphingolipid species but one of them, ceramide, is particularly important as being located in the middle of this complex metabolic pathway. Therefore, ceramide is essential for the synthesis of other sphingolipids and back-reactions catalyzed by different enzymes contribute to the ceramide pool by converting other types of sphingolipids, indicating that this is not a one way process, instead, it has a dynamic nature [7-9]. Ceramide is formed by the addition of a fatty acid chain with varying number of carbon atoms to sphingosine base. There are multiple mechanisms responsible for ceramide production in cells. Ceramide can be produced from serine and palmitoyl CoA in endoplasmic reticulum (ER) via de novo synthesis (Fig. 2) $[10,11]$. This pathway involves several chemical reactions and separate enzymes catalyzing each step. First condensation step is catalyzed by serine palmitoyltransferase producing 3ketosphinganine (3-ketodihydrosphingosine) [12]. In subsequent steps, 3-ketosphinganine is converted to sphinganine (dihydrosphingosine) that would in turn serve as a substrate for dihydroceramide synthase (known as Lass or CerS) for acylation to dhCer $[13,14]$. This step is reversible and the back-reaction is catalyzed by ceramidases (CDase). Desaturation of dhCer produces ceramide in the last step of de novo synthesis pathway (Fig. 1) [15, 16]. Alternatively, ceramides can be synthesized from sphingomyelin by the catalysis of sphingomyelinase (SMase) [17, 18]. According to pH optima, SMases are named as acid SMase, neutral SMase, and alkaline SMase. Not surprisingly, these classes of enzymes have preference for subcellular localizations due to their optimal $\mathrm{pH}$ ranges. Moreover, generation of ceramides by different SMases is thought to attribute different functions to the ceramide products, which might have distinct and profound effects in signaling [19]. Reverse reaction is also possible by the catalysis of sphingomyelin 


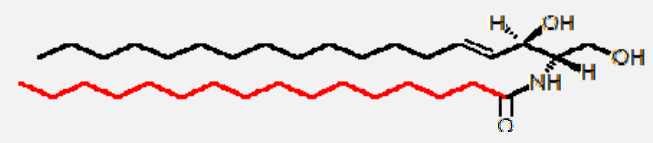

\section{Ceramide}

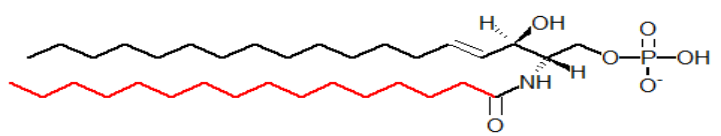

Ceramide-1-Phosphate

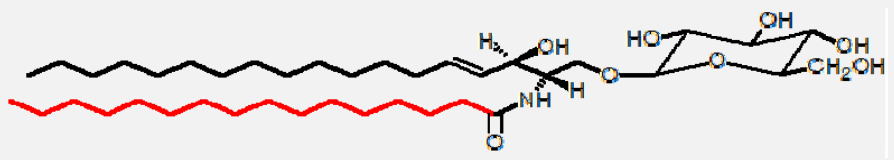

Glucosylceramide
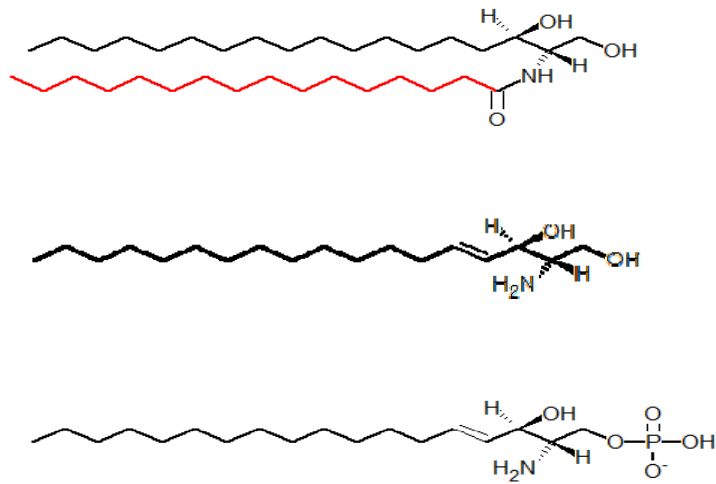

Dihydroceramide

Sphingosine

Sphingosine-1-Phosphate

Fig. (1). Chemical structures of various bioactive sphingolipids. Ceramide and its derivatives shown in this figure contain 16 carbon atoms in the fatty acid chain and hence named as C16-ceramides.

synthase producing sphingomyelin from ceramide with a process involving utilization of phosphatidylcholine and liberation of diacylglycerol meanwhile [20]. This reaction specifically takes place in Golgi and ceramides that would be used for SM production are transported to this compartment by ceramide transfer protein, CERT [21]. As the last mechanism, degradation of complex sphingolipids can also result in the production of ceramides by a process called "salvage pathway" [22]. This pathway involves intermediates such as GluCer and galactosylceramide (GalCer) as the direct products of degradation; but they are hydrolyzed to ceramides by specific enzymes subsequently (Fig. 2) [23, 24].

Sphingosine is synthesized from ceramides by CDases by the removal of amide-linked fatty acid chain. Similar to SMases, there are different types of CDases classified according to their optimal $\mathrm{pH}$ for enzymatic catalysis as acid CDases, neutral CDases and alkaline CDases [25-27]. In this mechanism, ceramides can also be derived from sphingosine by ceramide synthase (encoded by a family of genes called Lass genes - longevity assurance homologue-1 of yeast Lag1) in the reverse reaction. Upon its synthesis, sphingosine can be modified to sphingosine-1-phosphate (S1P) by sphingosine kinase (SphK) [28]. Sphingosine phosphatase can catalyze the reverse reaction by removing the phosphate group. S1P can be further metabolized by S1P lyase yielding ethanolamine phosphate and hexadecanal. This is an irreversible step but products can be converted into palmitate for re-utilization in the sphingolipid metabolism (Fig. 2) [29].
Glucosylceramide (GluCer) is synthesized from ceramides in Golgi by GluCer synthase (GCS) and it serves as a substrate for the synthesis of complex glycosphingolipids in the same subcellular compartment. Unlike CERT-mediated transport that is seen during SM production, ceramides are carried to Golgi by vesicles budding off directly from ER without the direct involvement of a protein transporter [30]. However, GluCer associates with some proteins for transport through Golgi in the subsequent reactions leading to the synthesis of complex glycosphingolipids [31, 32]. GluCer can be converted back to ceramide by glucosylceramidase [33]. However, ceramide is not limited to the biochemical conversions listed above. It can also undergo phosphorylation by the catalysis of ceramide kinase [34] and this modification changes its characteristics and downstream targets profoundly as it will be discussed in the following section.

\section{CELLULAR ROLES OF BIOACTIVE SPHINGOLIPIDS}

Accumulating body of evidence for decades suggests that bioactive sphingolipids are involved in the regulation of many cellular processes. Deregulation of sphingolipid metabolism is implicated in several forms of metabolic disease and malignancies [35-37]. Moreover, different forms of sphingolipids exert distinct regulatory functions. Therefore, a delicate balance among lipid players needs to be maintained for homeostasis under varying environmental conditions [38-41]. 


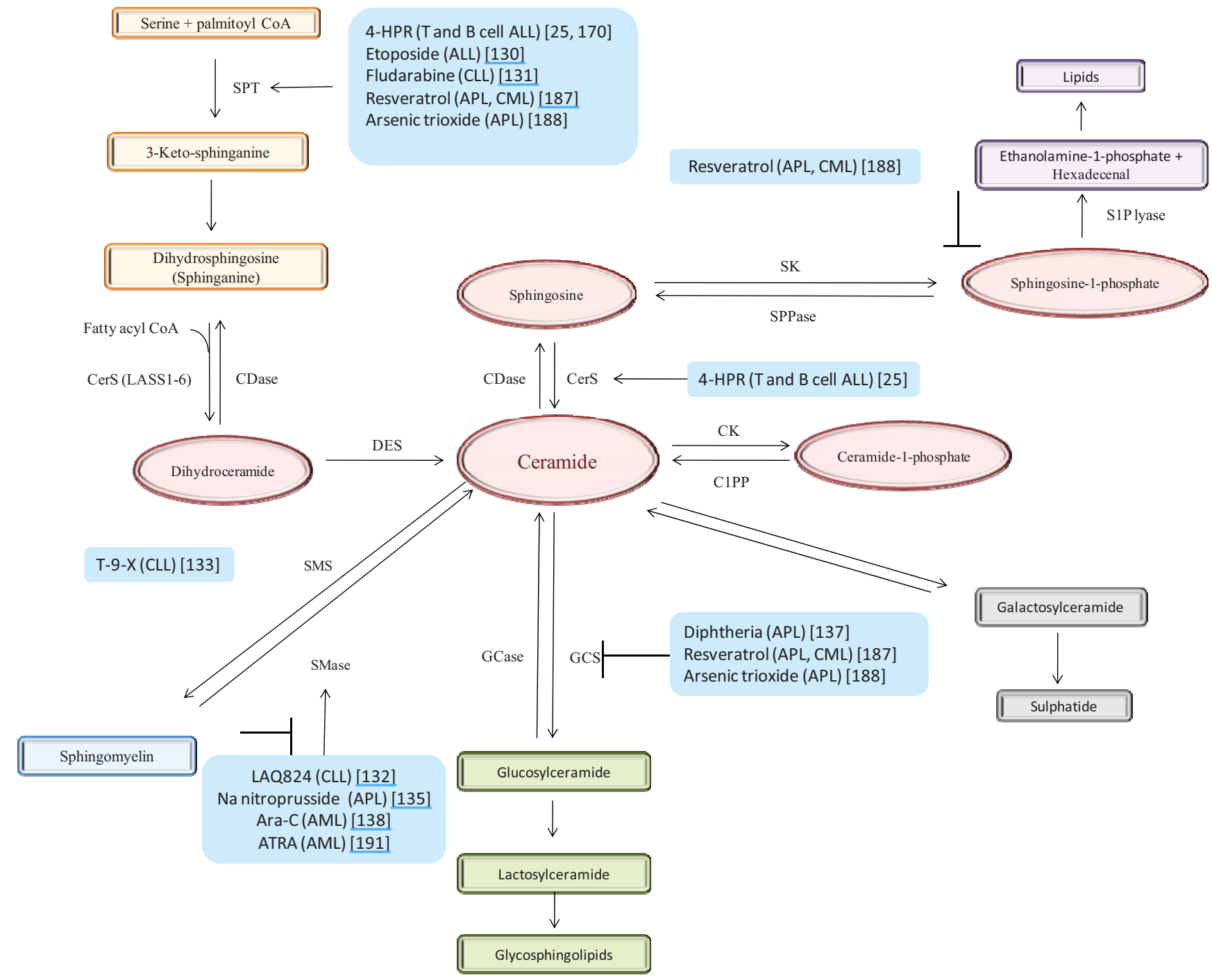

Fig. (2). Biochemical inter-conversions of sphingolipid species and compounds inhibiting or inducing the specific enzymes in this pathway. CerS (LASS), ceramide synthase; CDase, ceramidase; DES, dihydroceramide desaturase; SMS, sphingomyelin synthase; SMase, sphingomyelinase; GCS, glucosyl ceramide synthase; GCase, glucosyl ceramidase; CK, ceramide kinase; S1P, sphingosine-1-phosphate; SPPase, S1P phosphatase; SK, sphingosine kinase; C1PP, ceramide-1-phosphate phosphatase. T-9-X, tricyclodecan-9-yl-xanthogenate; LAQ824, histone deacetylase inhibitor; 4-HPR, N-(4-hydroxyphenyl) retinamide; ATRA, all-trans-retinoic acid; Ara-C, cytosine arabinoside; ALL, acute lymphoblastic leukemia; AML, acute myeloid leukemia; CLL, chronic lymphoblastic leukemia; CML, chronic myeloid leukemia; APL, acute promyelocytic leukemia.

\section{a). Ceramide Derivatives: Ceramide, C1P, GluCer, and dhCer}

Ceramide is maybe the most intensely studied sphingolipid among the others. Therefore there is a wide array of data about the roles of ceramide in different physiological and pathophysiological conditions. One of the well known functions of ceramides is involvement in type-I programmed cell death, or apoptosis (this is not valid for every single type of ceramide; in fact fatty acid chain length has a deterministic effect on the behavior of the ceramide as more will be discussed about this below). In numerous different model systems, ceramides are shown to induce apoptosis with some overlapping and non-overlapping mechanisms. For instance, de novo ceramide generation was found to be important for triggering apoptosis specifically in melanoma cells as evidenced by the lack of apoptosis when serine palmitoyltransferase activity is blocked [42]. However in prostate cancer cancer cell lines, ceramide-mediated apoptosis appeared to be driven by Akt dephosphorylation through protein phosphatase 2A activity [43]. Similarly, in another study, ceramide analogs were shown to induce apoptosis by affecting mi- tochondria along with the concomitant dephosphorylation of Akt [44]. Supporting this mechanism, ceramide channels formed on the mitochondrial membranes were documented to be important for the release of pro-apoptotic factors to cytosol [45]. This finding was recapitulated by various other studies involving different model systems. Interestingly, a recent report has shown that mitochondrially-targeted ceramide analog LCL29 is more potent for retarding cell growth in MCF7 breast cancer cell line through autophagy and apoptosis compared to uncharged ceramides suggesting that targeting ceramides to mitochondria might enhance the efficacy of the compound for therapeutic purposes [46]. In another report, upregulation of ceramide correlated with the activation of proapoptotic genes; and apoptosis is inhibited by blocking the ceramide pathway in breast cancer cells indicating the importance of ceramides in the actual apoptotic induction [47]. Cytochrome $\mathrm{C}$ release is mediated directly by ceramides as shown in the isolated mitochondria [48]. Ceramide-mediated apoptosis is not only important for cancer cell death but also thought to be present in various healthy cells includ- 
ing macrophages and developing embryos which suggests its importance for maintaining homeostasis in healthy cells as well [49, 50]. Furthermore, apoptotic induction by ceramides is a known mechanism for stress-induced cell death as shown by numerous studies [51-54]. As an example, conversion of sphingomyelin to ceramide was documented during apoptosis upon heat-stress [55]. A similar pathway is responsible for insulinoma cell death induced by ER-stress [56, 57]. However, there are some other studies indicating that ceramides might be dispensable for cell death under certain stress conditions $[54,58]$ preventing us to generalize ceramide-mediated apoptosis as "the mechanism" for stress-induced cell death. Moreover, ceramides having long fatty acid chains behave somewhat differently in the regulation of cellular processes. While ceramides are generally known to exert growth suppressive and apoptotic functions, C16-ceramide was documented to be antiapoptotic and provide protection against cell death upon ER stress [59]. Similar observations were done in other models attributing anti-apoptotic roles to long chain ceramides $[60,61]$.

C1P has opposing regulatory roles compared to ceramides. Unlike majority of ceramides, C1P is known to induce DNA replication, suppress apoptosis and favor survival of cells [62, 63]. Protein kinase $\mathrm{C}-\alpha$ was shown to be essential for the proliferative effects of C1P [64]. In a study involving macrophages, suppression of apoptosis by $\mathrm{C} 1 \mathrm{P}$ was shown to be taking place via inhibition of de novo ceramide synthesis pathway [65]. Nitric oxide (NO) is also thought to have roles in $\mathrm{C} 1 \mathrm{P}$-mediated survival as evidenced by the abrogation of pro-survival effects in the presence of inhibitors for NO synthase [66]. In macrophages, C1P activates PI3 kinase, JNK and ERK1/2 pathways to mediate pro-survival effects [67]. On the other hand, C1P analogs were documented to exert anti-inflammatory functions through suppression of TNF- $\alpha$ and induction of IL-10 production in macrophages [68]. This role was confirmed by various other groups as well, attributing the importance to $\mathrm{C} 1 \mathrm{P}$ in the regulation of inflammatory response [69-71]. Besides this, $\mathrm{C} 1 \mathrm{P}$ is also thought to have roles in the regulation of intracellular $\mathrm{Ca}^{2+}$ levels [72-74].

GluCer is another type of proliferative sphingolipids and it has roles in the development of chemotherapeutic resistance [75-77]. Multidrug transporter, P-glycoprotein (P-gp), was shown to potentiate ceramide glycosylation, and addition of GCS inhibitors sensitized cells to chemotherapy [78]. Chemoresistance conferred by GluCer is mediated by the inhibition of NADPH oxidase; hence augmenting NADPH oxidase activity provides sensitivity to chemotherapy [75]. GluCer was also shown to directly upregulate MDR1 expression via cSrc and $\beta$-catenin pathways producing chemoresistant cancer subtypes [79]. In leukemic cell lines, GCS was found to contribute drug resistance by upregulating anti-apoptotic Bcl-2 [80]. Upregulation of GCS correlates with poor prognosis and aggressive nature of the neoplasm as shown by studies on different cancer models $[81,82]$. GluCer is not only important for conferring chemotherapeutic resistance to cancer cells, but it is also important for the pathophysiology of several disorders including Gaucher disease, polycystic kidney disease and asthma [83-85]. Membrane trafficking, natural killer lymphocyte polarization and neuronal activation can be given as examples of other cellular processes involving GluCer [86-88].

Dihydroceramide (dhCer) has several functions in cells some of which looks a bit controversial. By some groups dhCer was shown not to be important for inducing apoptosis and cell cycle arrest $[89$, 90]. Opposite to those observations, in some other studies, a low but considerable level of apoptotic induction is linked to dhCer [91, 92]. dhCer was shown to increase in response to 4-HPR chemotherapy in ovarian cancers concomitantly with the increased levels of apoptosis by a process reversed by sphingosine kinase activity [ 25 , 93]. In another study, inhibition of dhCer synthesis correlated with reduced viability in T-cell leukemia line [94]. Ceramide-to-dhCer ratio was shown to be a determinant in the apoptotic decision in another report, possibly by modulating ceramide channels through conversion of ceramide to dhCer [95]. Loss of dhCer was correlated with rapid cell growth and increased apoptosis interestingly, and this phenotype was rescued with the activation of dhCer synthesis in some neurodegerative disorders [96]. Autophagy, self-destruction of the cellular components, is another process in which dhCer is thought to have regulatory roles $[97,98]$. In some studies it was documented that not the increased intracellular dhCer level; but the conversion of dhCer into other sphingolipids per se is responsible for some of the listed phenotypes above [99].

\section{b). Sphingosine Derivatives: Sphingosine and S1P}

Sphingosine is a growth suppressive and apoptotic sphingolipid, like ceramide. This feature of sphingosine is documented in several cell types including both malignant and healthy cells [100]. Leukemic cells including multidrug resistant subtypes [101-103], various forms of carcinoma [104], and soft tissue sarcoma cells [105] were shown to undergo apoptosis upon exposure to sphingosine or in response to increased intracellular levels of sphingosine. Apoptotic induction mechanism of sphingosine was shown to be dependent on cytochrome c release from mitochondria in neurons and astrocytes [106]. In some other studies, sphingosine was found to exert its functions through the inhibition of protein kinase C [107]. This particular sphingolipid also has regulative functions for phagocytosis as shown in alveolar macrophages [108]. In this study, conversion of ceramides into sphingosine impaired clearance of apoptotic bodies by macrophages in a dose-dependent manner.

Sphingosine-1-phosphate (S1P) plays a totally different role in the regulation of cellular fate. It antagonizes ceramide and sphingosine and favors cell survival. When endothelial cells are beamed with ionizing radiation, $\mathrm{S} 1 \mathrm{P}$ was shown to activate AKT pathway to protect the cells from apoptosis [109]. Loss of sphingosine kinase activity was shown to increase the sensitivity to the DNA damaging chemotherapy with the concomitant increase in reactive oxygen species [110]. Blocking S1P production was shown to have possible implications in the suppression of angiogenesis which is an instrumental process for tumor growth $[111,112]$. Other than its implications in cancer, S1P signaling was shown to be important in various other processes as well. For instance, recruitment of inflammatory macrophages in atherosclerosis appears to be mediated by S1Pdriven chemotaxis [113]. It is also known to be important for the migration of other cell types including myofibroblasts [114], osteoclast precursors [115] and hepatic stellate cells [116]. S1P signaling is also thought to be important in multiple sclerosis provided the drugs modulating S1P receptor activity could be used as good therapeutic options for the relapsing disease [117, 118]. Furthermore, S1P appears to be a promising target for the treatment of rheumatoid arthritis (as reviewed in [119]) and asthma [120]. Interestingly, in a study of murine collagen-induced arthritis model, two isoenzymes responsible for the production of S1P (sphingosine kinase 1 and sphingosine kinase 2) were shown to have distinct cellular functions [121].This surprising finding was also confirmed by other groups in different models [122-124]. In one of those studies, SphK1 and SphK2 were shown to have opposing functions for the regulation of ceramide biosynthesis [124]. Unlike SphK1, SphK2 was found to be inhibitory for cell growth through calciummediated apoptosis. Authors of this study argue that cellular location of the S1P product is deterministic to its function as evidenced by anti-apoptotic to pro-apoptotic conversion of SphK1 upon targeting to ER.

\section{SPHINGOLIPIDS IN THE PERSPECTIVE OF CHEMO- THERAPEUTIC RESPONSE}

As seen above, bioactive sphingolipids play important roles in the regulation of several cellular processes. Programmed cell death and the opposing activation of pro-survival mechanisms are among 
those processes which are regulated by sphingolipids, at least in part. Therefore, not surprisingly, sphingolipids are implicated in the chemotherapeutic response of various anti-cancer agents on various types of malignancies. By numerous studies it was shown that accumulation of apoptotic sphingolipids such as ceramide and sphingosine is responsible for the cytotoxicity of the chemotherapeutic agent in question. For instance, accumulation of ceramide was found to damage mitochondria and induce apoptosis in a caspase-independent manner upon curcumin treatment in prostate cancer cells [125]. Another study supported this observation by showing C6 ceramides contribute to sensitization to curcumin in melanoma cells [126]. Generation of ceramides was shown to reduce the viability of hormone-resistant prostate cancer cells upon treatment with the cannabinoid $\mathrm{R}+$ methanandamide as evidenced by the reversal of the cytotoxicity by the addition of ceramide synthase inhibitor Fumosin B1 [127]. In gastrointestinal tumors, combination of targeted therapeutics vorinostat and sorafenib upregulated CD95 through ceramide signaling which in turn resulted in the increase of reactive oxygen species for killing the cancerous cells [128]. De novo pathway is suspected to be the important mechanism in this type of cytotoxicity as evidenced by the increased levels of dhCer which is the intermediate product of this pathway. A similar observation was done in ovarian cancer cells treated with synthetic retinoids [129]. In this study, mass spectrometry analysis identified more than 30 species of sphingolipids, dhCer species being in particular, increased upon drug treatment,. Etoposide induced apoptosis through increasing intracellular ceramides by activating serine palmitoyltransferase enzyme in Molt-4 human ALL cells [130]. Fludarabine induced apoptosis in WSU and JVM-2 CLL cells through inducing de novo ceramide generation and increasing sphingomyelinase enzyme activity [131]. Histone deacetylase inhibitor LAQ824 triggered apoptosis in U937 cells through ceramide generation by activating acid sphingomyelinase [132]. Tricyclodecan-9-yl-xanthogenate induced apoptosis in U937 cells in a time and dose-dependent manner by inhibiting SMS activity and increasing intracellular levels of ceramides [133]. Photodynamic treatment resulted in a time-dependent ceramide accumulation in U937 cells [134]. Sodium nitroprusside elevated ceramide levels through increasing the activity of neutral sphingomyelinase enzyme activity in acute promyelocytic leukemia cells [135]. Ionizing radiation resulted in hydrolysis of SM and generation of ceramide through the activation of neutral sphingomyelinase in TF-1-33 AML cells [136]. Diphtheria toxin conjugated to granulocytemacrophage colony-stimulating factor (DT(388)-GM-CSF) elevated ceramide levels significantly and decreased the viability in vincristine resistant HL60 cells. Similar results were obtained for parental sensitive counterparts [137]. Treatment of HL60 cells with cytosine arabinoside increased ceramide levels in a time- and dosedependent manner. Researchers detected these increases as early as $5 \mathrm{~min}$ after cytosine arabinoside exposure. On the other hand, cytosine arabinoside also activated neutral sphingomyelinase [138]. Forced expression of SK1 in LAMA84 CML cells inhibited imatinib-induced apoptosis while inhibition of SK1 with F-12509a or application of SK1 siRNA induced apoptosis in both parental sensitive and imatinib-resistant LAMA84 cells [139].

In majority of the studies presented above and shown in Fig. (2), elevation of the apoptotic sphingolipids was found to be coincident with the chemotherapy, suggesting that these sphingolipids may be playing effector roles in those mechanisms. In agreement with this point of view, there are numerous other reports in which exogenous sphingolipids (short chain ceramides in particular) were provided to the cells and cancer eradication was obtained as well [140-142]. In fact, providing synthetic sphingolipids might have better outcomes for therapeutic purposes since availability and rapid metabolism of natural sphingolipids limit their utilization. FTY720 is a chemically synthesizable analog for sphingosine [143] which was shown to be effective for the treatment of CLL and CML [144, 145]. Mechanism of action is dependent on protein phosphatase 2A (PP2A) activation resulting in shutting down of the signaling pathways driving leukomogenesis [146-148]. While FTY720 is phosphorylated by sphingosine kinases (where SphK2 has higher potential for this process) $[149,150]$; VPC23019 is a synthetic compound analogous to S1P which directly antagonizes S1P(1) and S1P(2) receptors by competing with S1P [151]. However novel compounds are still being synthesized to enhance the solubility and in vivo efficacy of such antagonists [152]. These studies show that particular sphingolipid species can be used for obtaining better clearance of cancerous cells as distinct chemotherapeutic options. Addressing the same issue, many other papers have shown that manipulating sphingolipid metabolism might have important applications for obtaining better responses to conventional chemotherapy and for overcoming chemotherapeutic resistance developed by many tumors in the course of cancer progression. The main logic behind those studies can be summarized as suppressing the enzymes responsible for the production of growthpromoting sphingolipids $[153,154]$ and/or activating enzymes responsible for the production of apoptotic ceramides and sphingosine $[155,156]$. Since efficacy of such an approach has been proven by several studies, it is currently a hot topic for developing new therapies to the variety of cancer types (as reviewed in $[35,157]$ ). Short chain ceramides with apoptotic induction capabilities [158]; GluCer and S1P with undesired contribution to drug resistance and cancer cell survival $[78,79,159]$ come forward as good targets for manipulation in this manner. Sphingolipids might play effector roles as seen in the numerous studies above; but they are also utilized for better drug delivery options. There are some studies indicating that sphingolipid-conjugated nanoparticles are more effective in delivering the chemotherapeutic agent to cancer cells specifically $[160,161]$. This approach was tested in various xenograft and syngeneic tumor models in mice and proven to be effective for better responses to chemotherapy $[162,163]$. Taken together, gathered data attribute an important role to sphingolipid metabolism and its individual components for the development of effective therapeutics and for overcoming drug resistance which is a major challenge in clinic for obtaining the desired response to the chemotherapeutic options in hand.

\section{TARGETING SPHINGOLIPID METABOLISM FOR THE TREATMENT OF LEUKEMIAS}

Leukemia research is one of broadest areas in which targeted therapies are most advanced lately. The more we understand the characteristics of malignant transformation in blood-forming tissues, the more we develop therapeutic options that work specifically on cancer cells and give the least damage to healthy cells in the body as possible. However, sadly enough, not all types of blood cancers are provided with such therapeutic options. Besides that, in the course of treatment, some leukemias develop resistance even to targeted drugs and disease relapses with more aggressive phenotypes being refractory to multiple other chemotherapeutic drugs. These undesired outcomes make researchers look for new therapies overcoming the caveats of the current options. Sphingolipid metabolism appears to be a good target for that purpose. This section of the article is concentrated on possible applications of this approach for the treatment of leukemias.

Acute lymphoblastic leukemia (ALL) occurs mainly at childhood with unknown direct causative factors. However some genetic changes altering the expressions of hematopoietic transcription factors are suspected to be responsible for the malignant transformation [164] (for more detailed information about characteristics of ALL, please see reviews [165] and [166]). A recent report showed that membrane-bound sialidase, an enzyme responsible for the degradation of gangliosides, was downregulated in ALL; and when sialidase was overexpressed, apoptotic induction was obtained with the concomitant increase in ceramide levels and decrease in lactosylceramide [167]. By another report, ganglioside GD3 was found to be upregulated [168] and O-acetylated in ALL cells rendering it 
unable to induce apoptosis suggesting that it is a survival trick adopted by leukemic cells [169]. As mentioned briefly in the previous sections, retinoid 4-HPR causes elevation of ceramide levels and induces apoptosis. This induction was shown to be malignancyspecific for ALL cells as evidenced by increased cytotoxicity in leukemic cells whereas non-transformed cells were unaffected [170]. Taken together, those data indicate interventions increasing cellular ceramide levels might be a promising approach for effective ALL therapies. Gangliosides such as GD3 might have important implications for the development of immunotherapy to ALL on the other hand. In this approach, highly upregulated gangliosides on the cell surface could be used as markers of malignant cells. Another study showed that significant amounts of antibodydependent cellular cytotoxicity could be obtained in serum when ALL cells are treated with monoclonal antibodies recognizing GD3 [171]. In addition to this, CD1d-bearing ALL subsets are known to present $\alpha$-galactosylceramide to CD1d-restricted T-cells [172]. Even though this event was shown as a poor prognostic marker, it may lead to new immunotherapeutic interventions. For instance, $\alpha-$ galactosylceramide-pulsed antigen presenting cells and in vitro expanded natural killer T cells (NKT cells) were shown to be effective for immunotherapeutic clearance of solid tumors when delivered to tumor microenvironment [173-175]. While not all $\alpha-$ galactosylceramide analogs are effective in the same manner [176, 177], KRN7000 in particular, was shown to stimulate invariant natural killer T cells (iNKT cells) and evoke an immune response against viruses and tumors [178-180]. Because of its potential, there has been phase-I and phase-II trials assessing the efficacy of KRN7000 in various solid tumors and myelomas (with the identifiers of NCT00003985 and NCT00698776 respectively) [181-185].

Acute myeloid leukemia (AML) originates from myeloid lineage unlike ALL. Radiation and chemotherapy are among the causative factors identified so far [186]. Ceramide appears to be important in the chemotherapeutic cytotoxicity for AML cells as well [187, 188]. Studies with AML cells showed that ceramides might be important for heat-shock induced apoptosis [189]. Immunologic clearance of leukemic cells by TRAIL-induced apoptosis was observed after pulsing dendritic cells with $\alpha$-galactosylceramide but not prior to pulsing, suggesting that other sphingolipids might have roles for other effective therapeutic approaches [190]. Interestingly, ceramides were shown to be potent to induce differentiation in AML cells which somewhat show the characteristics of immature stem cells $[131,191]$. Some gangliosides, neolacto-series and GM3 in particular, have similar roles for the differentiation of leukemic cells [192, 193]. P-glycoprotein, P-gp, (protein product of multi drug resistance 1 gene, MDR 1 ) is responsible for the drug resistance developed by different types of blood cancers including AML. P-gp was shown to induce conversion of ceramide to GluCer allowing cancer cell survival in addition to its direct drug-efflux functions [194, 195]. Overexpression of sphingosine kinase which is responsible for the production of proliferative S1P was shown to cause $M D R 1$-associated chemotherapeutic resistance in AML cell lines [196]. This observation was supported by other papers indicating that S1P upregulation is an important oncogenic achievement in the cancer progression producing refractory subtypes [197]. In the light of the data attributing essential roles to sphingolipids in the leukomogenesis and drug resistance, targeting sphingosine kinase pathway might be a promising approach to overcome chemoresistance for AML in particular.

Chronic lymphocytic leukemia (CLL) is the most common form of leukemia and it is characterized by elevated levels of immature white blood cells in bloodstream similarly to other leukemias, but CD5-positive B cells being in particular for this case. Various studies have shown that CLL is manifested by the lack of apoptosis as evidenced by accumulation of $\mathrm{G}_{0}$ quiescent cells [198]. Therefore re-activation of apoptotic pathway might be an effective approach to eradicate CLL. One aggressive form of this leukemia was shown to be efficiently eradicated and complete remission was obtained in rats through the delivery of liposomal short chain ceramides that target survivin pathway [199]. Besides this, lipid rafts and particular gangliosides are thought to have implications for obtaining better clearance of leukemic cells. GM1 and GM3 were found to be elevated in B-cell neoplasms as evidenced by various biochemical assessments [200, 201]. Even though studies making this discovery couldn't provide a satisfying explanation about their specific roles in malignancy, those sphingolipid species may have importance as diagnostic and therapeutic markers. Alemtuzumab, an antibody recognizing CD52 membrane proteins for immunotherapy, was shown to induce caspase-dependent cell death through lipid rafts which are rich in GM1 ganglioside [202]. Similar to ALL cases mentioned above, CD1d marker is also expressed on CLL cells and functions as $\alpha$-galactosylceramide presenting protein which may lead to development of novel immunotherapies to CLL through a similar approach that targets CD1d [203].

Chronic myeloid leukemia (CML) is maybe the most wellcharacterized leukemia type among others. A reciprocal translocation between chromosomes 9 and 22 is the driving force of malignant transformation in majority of the CML cases. That translocation results in the production of a fusion protein called BCR-ABL which shows constitutive tyrosine kinase activity in the cells [204]. BCR-ABL phosphorylates key proteins which in turn initiate proliferation and cell division. CML is the first leukemia type to which targeted chemotherapies are developed. There are drugs specifically binding to the fusion protein and blocking its kinase activity yielding reduction of leukemic cells in bloodstream to almost undetectable levels $[205,206]$. Similar to what is seen above; ceramides are thought to be important mediators of apoptosis in CML cells, and the delicate balance in sphingolipid rheostat was shown to be important for chemoresistance [207]. BCR-ABL might be competing with ceramides for providing survival abilities to leukemic cells as shown by a study indicating Abl kinase as a negative regulator of Fas-mediated cell death which is a convergent pathway for ceramide signaling [208, 209]. In addition to the importance of ceramides, some gangliosides (GM3 in particular here as well) were shown to be potent for inducing megakaryocytic differentiation of CML blasts [210, 211]. Moreover, desialylation of some glycoproteins by Neu2, a cytosolic sialidase, might block BCR-ABL/Src signaling [212]. Another report might be providing supportive evidence for such convergent mechanisms by showing that BCR-ABL regulates membrane GM1 levels and expression of ligands for natural killer cell receptors [213]. In this study, treatment of BCR-ABL positive cells with imatinib, a specific tyrosine kinase inhibitor, modulated levels of those molecules indicating that BCR-ABL is the actual factor responsible for this regulation. Some surface glycosphingolipids such as fucosylated gangliosides were shown as possible targets for immunotherapeutic interventions for CML since they may participate into the antigen presentation processes $[214,215]$

\section{CONCLUSION AND FUTURE PERSPECTIVES}

Regulation of cell death and survival is a complex process involving numerous pathways and dozens of proteins. Accumulated scientific knowledge so far attributed new roles to sphingolipids in this regulation besides their structural roles in membranes. Involvement of sphingolipids in these mechanisms appears to be not less important than previously known proteins and other small signaling molecules. In fact, deregulation of sphingolipid metabolism is now known as the causative factors for several diseases including but not limited to metabolic disorders and cancer. Moreover, with each study completed, scientists are discovering that sphingolipids are important mediators for mechanisms of action of several drugs, adding more importance to sphingolipids for the development of better therapeutic options, especially in the cancer area. Numerous reports have shown that altered ceramide metabolism upon chemo- 
therapy is a major contributor to the cytotoxicity [216-218]. These experiments showed that inhibition of enzymes responsible for the production of apoptotic sphingolipid species (or in some cases overexpression of opposing enzymes) abrogates the cytotoxicity of the drug, and conversely overexpression of the same enzymes correlated with increased chemotherapeutic sensitivity suggesting that certain sphingolipid species are important for cytotoxicity of the drug [219-221]. Some other studies have also shown that therapeutic efficacy of cancer drugs can be significantly enhanced in combination with growth-suppressive sphingolipids such as ceramides and sphingosine [222-224]. Therefore, manipulation of sphingolipid metabolism comes forward as a good intervention approach for novel therapies [225]. Importance of some sphingolipid species in chemotherapeutic response and upregulation of proliferative types in the case of drug resistance make researchers think that chemotherapeutic outcome can be improved significantly through altering sphingolipid metabolism. This approach provides an exciting hot topic for the development of better therapeutics in the future (as reviewed in [226] and [35]). Acute and chronic leukemias are among the cancer types upon which we built majority of our knowledge about the involvement of sphingolipids in cancer therapeutics. Hence, leukemias might be good starting points for incorporation of sphingolipids for new treatments. Specificity of some sphingolipid species for malignant cells makes this approach feasible and exciting enough to pursue. However, for applying sphingolipid based therapeutics to several other types of leukemias and cancers, we may need to develop ways to deliver cytotoxic species specifically to the malignant cells. By this way, this approach might be generalized for other types of cancers as well to obtain enhanced eradication of the malignant cells. In the light of the accumulating literature in this area, it is suffice to say that sphingolipid metabolism holds a significant importance for the future therapeutics of various cancers and shows promise for better results in clinic that would bring us closer to the ultimate aim: changing the nature of cancer from being deadly in many cases, to being curable.

\section{ACKNOWLEDGMENT}

We thank Dr. Elif Apohan for critically reviewing the manuscript. This study was supported by the Turkish Academy of Sciences Outstanding Young Investigator Program.

\section{REFERENCES}

[1] Obeid, L.M.; Linardic, C.M.; Karolak, L.A.; Hannun, Y.A. Programmed cell death induced by ceramide. Science, 1993, 259(5102), 1769-1771.

[2] Wang, G.; Silva, J.; Krishnamurthy, K.; Tran, E.; Condie, B.G.; Bieberich, E. Direct binding to ceramide activates protein kinase Czeta before the formation of a pro-apoptotic complex with PAR-4 in differentiating stem cells. J. Biol. Chem., 2005, 280(28), 2641526424.

[3] Zhou, H.; Summers, S.A.; Birnbaum, M.J.; Pittman, R.N. Inhibition of Akt kinase by cell-permeable ceramide and its implications for ceramide-induced apoptosis. J. Biol. Chem., 1998, 273(26), 16568-16575.

[4] Kim, M.Y.; Linardic, C.; Obeid, L.; Hannun, Y. Identification of sphingomyelin turnover as an effector mechanism for the action of tumor necrosis factor alpha and gamma-interferon. Specific role in cell differentiation. J. Biol. Chem., 1991, 266(1), 484-489.

[5] Le Stunff, H.; Galve-Roperh, I.; Peterson, C.; Milstien, S.; Spiegel, S. Sphingosine-1-phosphate phosphohydrolase in regulation of sphingolipid metabolism and apoptosis. J. Cell Biol., 2002, 158(6), 1039-1049.

[6] Patwardhan, G.A.; Liu, Y.Y. Sphingolipids and expression regulation of genes in cancer. Prog. Lipid Res., 2010.

[7] Breslow, D.K.; Weissman, J.S. Membranes in balance: mechanisms of sphingolipid homeostasis. Mol. Cell, 2010, 40(2), 267-279.

[8] Hannun, Y.A.; Obeid, L.M. Principles of bioactive lipid signalling: lessons from sphingolipids. Nat Rev Mol. Cell Biol., 2008, 9(2), 139-150.
[9] Bielawski, J.; Szulc, Z.M.; Hannun, Y.A.; Bielawska, A. Simultaneous quantitative analysis of bioactive sphingolipids by high-performance liquid chromatography-tandem mass spectrometry. Methods, 2006, 39(2), 82-91.

[10] Merrill, A.H., Jr.; Wang, E.; Mullins, R.E. Kinetics of long-chain (sphingoid) base biosynthesis in intact LM cells: effects of varying the extracellular concentrations of serine and fatty acid precursors of this pathway. Biochemistry, 1988, 27(1), 340-345.

[11] Nagiec, M.M.; Lester, R.L.; Dickson, R.C. Sphingolipid synthesis: identification and characterization of mammalian cDNAs encoding the Lcb2 subunit of serine palmitoyltransferase. Gene, 1996, 177(12), 237-241.

[12] Linn, S.C.; Kim, H.S.; Keane, E.M.; Andras, L.M.; Wang, E.; Merrill, A.H., Jr. Regulation of de novo sphingolipid biosynthesis and the toxic consequences of its disruption. Biochem. Soc. Trans., 2001, 29(Pt 6), 831-835.

[13] Lahiri, S.; Futerman, A.H. LASS5 is a bona fide dihydroceramide synthase that selectively utilizes palmitoyl-CoA as acyl donor. $J$. Biol. Chem., 2005, 280(40), 33735-33738.

[14] Pewzner-Jung, Y.; Ben-Dor, S.; Futerman, A.H. When do Lasses (longevity assurance genes) become CerS (ceramide synthases)?: Insights into the regulation of ceramide synthesis. J. Biol. Chem., 2006, 281(35), 25001-25005.

[15] Causeret, C.; Geeraert, L.; Van der Hoeven, G.; Mannaerts, G.P.; Van Veldhoven, P.P. Further characterization of rat dihydroceramide desaturase: tissue distribution, subcellular localization, and substrate specificity. Lipids, 2000, 35(10), 1117-1125.

[16] Geeraert, L.; Mannaerts, G.P.; van Veldhoven, P.P. Conversion of dihydroceramide into ceramide: involvement of a desaturase. Biochem. J., 1997, 327 ( Pt 1)125-132.

[17] Xu, R.; Sun, W.; Jin, J.; Obeid, L.M.; Mao, C. Role of alkaline ceramidases in the generation of sphingosine and its phosphate in erythrocytes. FASEB J., 2010, 24(7), 2507-2515.

[18] Clarke, C.J.; Snook, C.F.; Tani, M.; Matmati, N.; Marchesini, N.; Hannun, Y.A. The extended family of neutral sphingomyelinases. Biochemistry, 2006, 45(38), 11247-11256.

[19] Marchesini, N.; Hannun, Y.A. Acid and neutral sphingomyelinases: roles and mechanisms of regulation. Biochem. Cell Biol., 2004, 82(1), 27-44.

[20] Tafesse, F.G.; Ternes, P.; Holthuis, J.C. The multigenic sphingomyelin synthase family. J. Biol. Chem., 2006, 281(40), 29421-29425.

[21] Hanada, K.; Kumagai, K.; Yasuda, S.; Miura, Y.; Kawano, M.; Fukasawa, M.; Nishijima, M. Molecular machinery for nonvesicular trafficking of ceramide. Nature, 2003, 426(6968), 803809.

[22] Kitatani, K.; Idkowiak-Baldys, J.; Hannun, Y.A. The sphingolipid salvage pathway in ceramide metabolism and signaling. Cell Signal., 2008, 20(6), 1010-1018

[23] Kitatani, K.; Sheldon, K.; Rajagopalan, V.; Anelli, V.; Jenkins, R.W.; Sun, Y.; Grabowski, G.A.; Obeid, L.M.; Hannun, Y.A. Involvement of acid beta-glucosidase 1 in the salvage pathway of ceramide formation. J. Biol. Chem., 2009, 284(19), 12972-12978.

[24] Ichikawa, S.; Hirabayashi, Y. Glucosylceramide synthase and glycosphingolipid synthesis. Trends Cell Biol, 1998, 8(5), 198-202. Mao, Z.; Sun, W.; Xu, R.; Novgorodov, S.; Szulc, Z.M.; Bielawski, J.; Obeid, L.M.; Mao, C. Alkaline ceramidase 2 (ACER2) and its product dihydrosphingosine mediate the cytotoxicity of $\mathrm{N}-(4-$ hydroxyphenyl)retinamide in tumor cells. J. Biol. Chem., 2010, 285(38), 29078-29090.

[26] Ohlsson, L.; Palmberg, C.; Duan, R.D.; Olsson, M.; Bergman, T.; Nilsson, A. Purification and characterization of human intestinal neutral ceramidase. Biochimie, 2007, 89(8), 950-960.

[27] Bernardo, K.; Hurwitz, R.; Zenk, T.; Desnick, R.J.; Ferlinz, K. Schuchman, E.H.; Sandhoff, K. Purification, characterization, and biosynthesis of human acid ceramidase. J. Biol. Chem., 1995, 270(19), 11098-11102.

[28] Hait, N.C.; Oskeritzian, C.A.; Paugh, S.W.; Milstien, S.; Spiegel, S. Sphingosine kinases, sphingosine 1-phosphate, apoptosis and diseases. Biochim. Biophys. Acta, 2006, 1758(12), 2016-2026.

[29] Bandhuvula, P.; Saba, J.D. Sphingosine-1-phosphate lyase in immunity and cancer: silencing the siren. Trends Mol. Med., 2007, 13(5), 210-217.

[30] Halter, D.; Neumann, S.; van Dijk, S.M.; Wolthoorn, J.; de Maziere, A.M.; Vieira, O.V.; Mattjus, P.; Klumperman, J.; van 
Meer, G.; Sprong, H. Pre- and post-Golgi translocation of glucosylceramide in glycosphingolipid synthesis. J. Cell Biol., 2007, 179(1), 101-115.

[31] D'Angelo, G.; Polishchuk, E.; Di Tullio, G.; Santoro, M.; Di Campli, A.; Godi, A.; West, G.; Bielawski, J.; Chuang, C.C.; van der Spoel, A.C.; Platt, F.M.; Hannun, Y.A.; Polishchuk, R.; Mattjus, P.; De Matteis, M.A. Glycosphingolipid synthesis requires FAPP2 transfer of glucosylceramide. Nature, 2007, 449(7158), 6267.

[32] Eckford, P.D.; Sharom, F.J. P-glycoprotein (ABCB1) interacts directly with lipid-based anti-cancer drugs and platelet-activating factors. Biochem. Cell Biol., 2006, 84(6), 1022-1033.

[33] Carstea, E.D.; Murray, G.J.; O'Neill, R.R. Molecular and functional characterization of the murine glucocerebrosidase gene. Biochem. Biophys. Res. Commun., 1992, 184(3), 1477-1483.

[34] Wijesinghe, D.S.; Massiello, A.; Subramanian, P.; Szulc, Z.; Bielawska, A.; Chalfant, C.E. Substrate specificity of human ceramide kinase. J. Lipid Res., 2005, 46(12), 2706-2716.

[35] Ekiz, H.A.; Baran, Y. Therapeutic applications of bioactive sphingolipids in hematological malignancies. Int. J. Cancer, 2010, 127(7), 1497-1506.

[36] Duan, R.D.; Nilsson, A. Metabolism of sphingolipids in the gut and its relation to inflammation and cancer development. Prog. Lipid Res., 2009, 48(1), 62-72.

[37] Zeidan, Y.H.; Jenkins, R.W.; Korman, J.B.; Liu, X.; Obeid, L.M.; Norris, J.S.; Hannun, Y.A. Molecular targeting of acid ceramidase: implications to cancer therapy. Curr. Drug Targets, 2008, 9(8), 653-661.

[38] Mora, R.; Dokic, I.; Kees, T.; Huber, C.M.; Keitel, D.; Geibig, R.; Brugge, B.; Zentgraf, H.; Brady, N.R.; Regnier-Vigouroux, A. Sphingolipid rheostat alterations related to transformation can be exploited for specific induction of lysosomal cell death in murine and human glioma. Glia, 2010, 58(11), 1364-1383.

[39] Lavieu, G.; Scarlatti, F.; Sala, G.; Carpentier, S.; Levade, T.; Ghidoni, R.; Botti, J.; Codogno, P. Sphingolipids in macroautophagy. Methods Mol. Biol., 2008, 445159-173.

[40] Baumruker, T.; Prieschl, E.E. Sphingolipids and the regulation of the immune response. Semin. Immunol., 2002, 14(1), 57-63.

[41] Mandala, S.M.; Thornton, R.; Tu, Z.; Kurtz, M.B.; Nickels, J.; Broach, J.; Menzeleev, R.; Spiegel, S. Sphingoid base 1-phosphate phosphatase: a key regulator of sphingolipid metabolism and stress response. Proc. Natl. Acad. Sci. USA, 1998, 95(1), 150-155.

[42] Sauane, M.; Su, Z.Z.; Dash, R.; Liu, X.; Norris, J.S.; Sarkar, D.; Lee, S.G.; Allegood, J.C.; Dent, P.; Spiegel, S.; Fisher, P.B. Ceramide plays a prominent role in MDA-7/IL-24-induced cancerspecific apoptosis. J Cell Physiol, 2010, 222(3), 546-555

[43] Kim, S.W.; Kim, H.J.; Chun, Y.J.; Kim, M.Y. Ceramide produces apoptosis through induction of $\mathrm{p} 27$ (kip 1) by protein phosphatase 2A-dependent Akt dephosphorylation in PC-3 prostate cancer cells. J. Toxicol. Environ. Health A, 2010, 73(21-22), 1465-1476.

[44] Oh, J.E.; So, K.S.; Lim, S.J.; Kim, M.Y. Induction of apoptotic cell death by a ceramide analog in PC-3 prostate cancer cells. Arch Pharm Res, 2006, 29(12), 1140-1146.

[45] Siskind, L.J.; Feinstein, L.; Yu, T.; Davis, J.S.; Jones, D.; Choi, J.; Zuckerman, J.E.; Tan, W.; Hill, R.B.; Hardwick, J.M.; Colombini, M. Anti-apoptotic Bcl-2 Family Proteins Disassemble Ceramide Channels. J. Biol. Chem., 2008, 283(11), 6622-6630.

[46] Hou, Q.; Jin, J.; Zhou, H.; Novgorodov, S.A.; Bielawska, A.; Szulc, Z.M.; Hannun, Y.A.; Obeid, L.M.; Hsu, Y.T. Mitochondrially targeted ceramides preferentially promote autophagy, retard cell growth, and induce apoptosis. J. Lipid Res., 2011, 52(2), 278-288.

[47] Bandyopadhyay, S.; Zhan, R.; Wang, Y.; Pai, S.K.; Hirota, S.; Hosobe, S.; Takano, Y.; Saito, K.; Furuta, E.; Iiizumi, M.; Mohinta, S.; Watabe, M.; Chalfant, C.; Watabe, K. Mechanism of apoptosis induced by the inhibition of fatty acid synthase in breast cancer cells. Cancer Res., 2006, 66(11), 5934-5940.

[48] Richter, C.; Ghafourifar, P. Ceramide induces cytochrome c release from isolated mitochondria. Biochem. Soc. Symp., 1999, 6627-31.

[49] de Castro e Paula, L.A.; Hansen, P.J. Ceramide inhibits development and cytokinesis and induces apoptosis in preimplantation bovine embryos. Mol Reprod Dev, 2008, 75(6), 1063-1070.

[50] Huber, L.C.; Jungel, A.; Distler, J.H.; Moritz, F.; Gay, R.E.; Michel, B.A.; Pisetsky, D.S.; Gay, S.; Distler, O. The role of membrane lipids in the induction of macrophage apoptosis by microparticles. Apoptosis, 2007, 12(2), 363-374.

[51] Devillard, R.; Galvani, S.; Thiers, J.C.; Guenet, J.L.; Hannun, Y.; Bielawski, J.; Negre-Salvayre, A.; Salvayre, R.; Auge, N. Stress-induced sphingolipid signaling: role of type-2 neutral sphingomyelinase in murine cell apoptosis and proliferation. PLoS One, 2010, 5(3), e9826.

[52] Ichi, I.; Kamikawa, C.; Nakagawa, T.; Kobayashi, K.; Kataoka, R.; Nagata, E.; Kitamura, Y.; Nakazaki, C.; Matsura, T.; Kojo, S. Neutral sphingomyelinase-induced ceramide accumulation by oxidative stress during carbon tetrachloride intoxication. Toxicology, 2009, 261(1-2), 33-40.

[53] Deng, X.; Yin, X.; Allan, R.; Lu, D.D.; Maurer, C.W.; HaimovitzFriedman, A.; Fuks, Z.; Shaham, S.; Kolesnick, R. Ceramide biogenesis is required for radiation-induced apoptosis in the germ line of C. elegans. Science, 2008, 322(5898), 110-115.

[54] Verheij, M.; van Blitterswijk, W.J.; Bartelink, H. Radiationinduced apoptosis--the ceramide-SAPK signaling pathway and clinical aspects. Acta Oncol., 1998, 37(6), 575-581.

[55] Yabu, T.; Imamura, S.; Yamashita, M.; Okazaki, T. Identification of $\mathrm{Mg} 2+$-dependent neutral sphingomyelinase 1 as a mediator of heat stress-induced ceramide generation and apoptosis. J. Biol. Chem., 2008, 283(44), 29971-29982.

[56] Lei, X.; Zhang, S.; Bohrer, A.; Ramanadham, S. Calciumindependent phospholipase A2 (iPLA2 beta)-mediated ceramide generation plays a key role in the cross-talk between the endoplasmic reticulum (ER) and mitochondria during ER stressinduced insulin-secreting cell apoptosis. J. Biol. Chem., 2008 , 283(50), 34819-34832

[57] Lei, X.; Zhang, S.; Bohrer, A.; Bao, S.; Song, H.; Ramanadham, S. The group VIA calcium-independent phospholipase A2 participates in ER stress-induced INS-1 insulinoma cell apoptosis by promoting ceramide generation via hydrolysis of sphingomyelins by neutral sphingomyelinase. Biochemistry, 2007, 46(35), 10170-10185.

[58] Takahashi, E.; Inanami, O.; Asanuma, T.; Kuwabara, M. Effects of ceramide inhibition on radiation-induced apoptosis in human leukemia MOLT-4 cells. J. Radiat. Res. (Tokyo), 2006, 47(1), 19-25.

[59] Senkal, C.E.; Ponnusamy, S.; Bielawski, J.; Hannun, Y.A.; Ogretmen, B. Antiapoptotic roles of ceramide-synthase-6-generated C16-ceramide via selective regulation of the ATF6/CHOP arm of ER-stress-response pathways. FASEB J., 2010, 24(1), 296-308.

[60] Mancinetti, A.; Di Bartolomeo, S.; Spinedi, A. Long-chain ceramide produced in response to $\mathrm{N}$-hexanoylsphingosine does not induce apoptosis in CHP-100 cells. Lipids, 2009, 44(11), 10391046.

[61] Novgorodov, S.A.; Gudz, T.I.; Obeid, L.M. Long-chain ceramide is a potent inhibitor of the mitochondrial permeability transition pore J. Biol. Chem., 2008, 283(36), 24707-24717.

[62] Gomez-Munoz, A.; Kong, J.Y.; Salh, B.; Steinbrecher, U.P. Ceramide-1-phosphate blocks apoptosis through inhibition of acid sphingomyelinase in macrophages. J. Lipid Res., 2004, 45(1), 99-105.

[63] Gomez-Munoz, A.; Duffy, P.A.; Martin, A.; O'Brien, L.; Byun, H.S.; Bittman, R.; Brindley, D.N. Short-chain ceramide-1-phosphates are novel stimulators of DNA synthesis and cell division: antagonism by cell-permeable ceramides. Mol. Pharmacol., 1995, 47(5), 833-839.

[64] Gangoiti, P.; Granado, M.H.; Arana, L.; Ouro, A.; Gomez-Munoz, A. Activation of protein kinase C-alpha is essential for stimulation of cell proliferation by ceramide 1-phosphate. FEBS Lett., 2010, 584(3), 517-524.

[65] Granado, M.H.; Gangoiti, P.; Ouro, A.; Arana, L.; Gomez-Munoz, A. Ceramide 1-phosphate inhibits serine palmitoyltransferase and blocks apoptosis in alveolar macrophages. Biochim. Biophys. Acta, 2009, 1791(4), 263-272.

[66] Gangoiti, P.; Granado, M.H.; Arana, L.; Ouro, A.; Gomez-Munoz, A. Involvement of nitric oxide in the promotion of cell survival by ceramide 1-phosphate. FEBS Lett., 2008, 582(15), 2263-2269.

[67] Gangoiti, P.; Granado, M.H.; Wang, S.W.; Kong, J.Y.; Steinbrecher, U.P.; Gomez-Munoz, A. Ceramide 1-phosphate stimulates macrophage proliferation through activation of the PI3kinase/PKB, JNK and ERK1/2 pathways. Cell Signal., 2008, 20(4), 726-736. 
[68] Goldsmith, M.; Avni, D.; Levy-Rimler, G.; Mashiach, R.; Ernst, O.; Levi, M.; Webb, B.; Meijler, M.M.; Gray, N.S.; Rosen, H.; Zor, T. A ceramide-1-phosphate analogue, PCERA-1, simultaneously suppresses tumour necrosis factor-alpha and induces interleukin-10 production in activated macrophages. Immunology, 2009, 127(1), $103-115$.

[69] Jozefowski, S.; Czerkies, M.; Lukasik, A.; Bielawska, A.; Bielawski, J.; Kwiatkowska, K.; Sobota, A. Ceramide and ceramide 1-phosphate are negative regulators of TNF-alpha production induced by lipopolysaccharide. J. Immunol., 2010, 185(11), 69606973.

[70] Gomez-Munoz, A.; Gangoiti, P.; Granado, M.H.; Arana, L.; Ouro, A. Ceramide-1-phosphate in cell survival and inflammatory signaling. Adv. Exp. Med. Biol., 2010, 688118-130.

[71] Saxena, S.; Banerjee, M.; Shirumalla, R.K.; Ray, A. Ceramide kinase: a potential anti-inflammatory target? Curr. Opin. Investig. Drugs, 2008, 9(5), 455-462.

[72] Hinkovska-Galcheva, V.; Shayman, J.A. Ceramide-1-phosphate in phagocytosis and calcium homeostasis. Adv. Exp. Med. Biol., 2010, 688131-140

[73] Mitsutake, S.; Kumada, H.; Soga, M.; Hurue, Y.; Asanuma, F.; Nagira, M.; Deguchi, M.; Date, T.; Yokose, U.; Inagaki, Y.; Sugiura, M.; Kohama, T.; Igarashi, Y. Ceramide kinase is not essential but might act as an Ca2+-sensor for mast cell activation. Prostaglandins Other Lipid Mediat, 2010, 93(3-4), 109-112.

[74] Hinkovska-Galcheva, V.; VanWay, S.M.; Shanley, T.P.; Kunkel, R.G. The role of sphingosine-1-phosphate and ceramide-1phosphate in calcium homeostasis. Curr. Opin. Investig. Drugs, 2008, $9(11), 1192-1205$.

[75] Barth, B.M.; Gustafson, S.J.; Young, M.M.; Shanmugavelandy, S.S.; Kaiser, J.M.; Cabot, M.C.; Kester, M.; Kuhn, T.B. Inhibition of NADPH oxidase by glucosylceramide confers chemoresistance. Cancer Biol. Ther., 2010, $10(11)$.

[76] Li, R.; Manela, J.; Kong, Y.; Ladisch, S. Cellular gangliosides promote growth factor-induced proliferation of fibroblasts. J. Biol. Chem., 2000, 275(44), 34213-34223.

[77] Lucci, A.; Cho, W.I.; Han, T.Y.; Giuliano, A.E.; Morton, D.L.; Cabot, M.C. Glucosylceramide: a marker for multiple-drug resistant cancers. Anticancer Res., 1998, 18(1B), 475-480.

[78] Chapman, J.V.; Gouaze-Andersson, V.; Cabot, M.C. Expression of P-glycoprotein in $\mathrm{HeLa}$ cells confers resistance to ceramide cytotoxicity. Int. J. Oncol., 2010, 37(6), 1591-1597.

[79] Liu, Y.Y.; Gupta, V.; Patwardhan, G.A.; Bhinge, K.; Zhao, Y.; Bao, J.; Mehendale, H.; Cabot, M.C.; Li, Y.T.; Jazwinski, S.M. Glucosylceramide synthase upregulates MDR1 expression in the regulation of cancer drug resistance through $\mathrm{cSrc}$ and beta-catenin signaling. Mol. Cancer, 2010, 9145

[80] Liu, Y.; Xie, K.M.; Yang, G.Q.; Bai, X.M.; Shi, Y.P.; Mu, H.J.; Qiao, W.Z.; Zhang, B.; Xie, P. GCS induces multidrug resistance by regulating apoptosis-related genes in $\mathrm{K} 562 / \mathrm{AO} 2$ cell line. Cancer Chemother. Pharmacol., 2010, 66(3), 433-439.

[81] Sun, C.C.; Zhang, Z.; Zhang, S.Y.; Li, J.; Li, Z.L.; Kong, C.Z. Upregulation of glucosylceramide synthase in urinary bladder neoplasms. Urol. Oncol., 2010.

[82] Ruckhaberle, E.; Karn, T.; Hanker, L.; Gatje, R.; Metzler, D.; Holtrich, U.; Kaufmann, M.; Rody, A. Prognostic relevance of glucosylceramide synthase (GCS) expression in breast cancer. $J$. Cancer Res. Clin. Oncol., 2009, 135(1), 81-90.

[83] Bodamer, O.A.; Hung, C. Laboratory and genetic evaluation of Gaucher disease. Wien Med Wochenschr, 2010

[84] Natoli, T.A.; Smith, L.A.; Rogers, K.A.; Wang, B.; Komarnitsky, S.; Budman, Y.; Belenky, A.; Bukanov, N.O.; Dackowski, W.R.; Husson, H.; Russo, R.J.; Shayman, J.A.; Ledbetter, S.R.; Leonard, J.P.; Ibraghimov-Beskrovnaya, O. Inhibition of glucosylceramide accumulation results in effective blockade of polycystic kidney disease in mouse models. Nat. Med., 2010, 16(7), 788-792.

[85] Karman, J.; Tedstone, J.L.; Gumlaw, N.K.; Zhu, Y.; Yew, N.; Siegel, C.; Guo, S.; Siwkowski, A.; Ruzek, M.; Jiang, C.; Cheng, S.H. Reducing glycosphingolipid biosynthesis in airway cells partially ameliorates disease manifestations in a mouse model of asthma. Int. Immunol., 2010, 22(7), 593-603.

[86] Santha, P.; Oszlacs, O.; Dux, M.; Dobos, I.; Jancso, G. Inhibition of glucosylceramide synthase reversibly decreases the capsaicin- induced activation and TRPV1 expression of cultured dorsal root ganglion neurons. Pain, 2010, 150(1), 103-112.

[87] Stefanic, S.; Spycher, C.; Morf, L.; Fabrias, G.; Casas, J.; Schraner, E.; Wild, P.; Hehl, A.B.; Sonda, S. Glucosylceramide synthesis inhibition affects cell cycle progression, membrane trafficking, and stage differentiation in Giardia lamblia. J. Lipid Res., 2010, 51(9), 2527-2545

[88] Ben Ya'acov, A.; Lalazar, G.; Livovsky, D.M.; Kanovich, D.; Axelrod, E.; Preston, S.; Schwarzmann, G.; Ilan, Y. Decreased STAT-1 phosphorylation by a thio analogue of beta-Dglucosylceramide is associated with altered NKT lymphocyte polarization. Mol. Immunol., 2009, 47(2-3), 526-533.

[89] Ahn, E.H.; Schroeder, J.J. Sphingoid bases and ceramide induce apoptosis in HT-29 and HCT-116 human colon cancer cells. Exp. Biol. Med. (Maywood), 2002, 227(5), 345-353.

[90] Bielawska, A.; Crane, H.M.; Liotta, D.; Obeid, L.M.; Hannun, Y.A. Selectivity of ceramide-mediated biology. Lack of activity of erythro-dihydroceramide. J. Biol. Chem., 1993, 268(35), 2622626232.

[91] Shikata, K.; Niiro, H.; Azuma, H.; Ogino, K.; Tachibana, T. Apoptotic activities of $\mathrm{C} 2$-ceramide and $\mathrm{C} 2$-dihydroceramide homologues against HL-60 cells. Bioorg. Med. Chem., 2003 , 11(13), 2723-2728

[92] Shikata, K.; Niiro, H.; Azuma, H.; Tachibana, T.; Ogino, K. Synthesis of non-natural C2-homo-ceramide and its apoptotic activity against HL-60 cells. Bioorg. Med. Chem. Lett., 2003, 13(4), 613-616.

[93] Illuzzi, G.; Bernacchioni, C.; Aureli, M.; Prioni, S.; Frera, G.; Donati, C.; Valsecchi, M.; Chigorno, V.; Bruni, P.; Sonnino, S. Prinetti, A. Sphingosine kinase mediates resistance to the synthetic retinoid N-(4-hydroxyphenyl)retinamide in human ovarian cancer cells. J. Biol. Chem., 2010, 285(24), 18594-18602.

[94] Munoz-Olaya, J.M.; Matabosch, X.; Bedia, C.; Egido-Gabas, M.; Casas, J.; Llebaria, A.; Delgado, A.; Fabrias, G. Synthesis and biological activity of a novel inhibitor of dihydroceramide desaturase. Chem. Med. Chem., 2008, 3(6), 946-953.

[95] Stiban, J.; Fistere, D.; Colombini, M. Dihydroceramide hinders ceramide channel formation: Implications on apoptosis. Apoptosis, 2006, 11(5), 773-780.

[96] Schulz, A.; Mousallem, T.; Venkataramani, M.; Persaud-Sawin, D.A.; Zucker, A.; Luberto, C.; Bielawska, A.; Bielawski, J.; Holthuis, J.C.; Jazwinski, S.M.; Kozhaya, L.; Dbaibo, G.S.; Boustany, R.M. The CLN9 protein, a regulator of dihydroceramide synthase. J. Biol. Chem., 2006, 281(5), 2784-2794.

[97] Separovic, D.; Kelekar, A.; Nayak, A.K.; Tarca, A.L.; Hanada, K.; Pierce, J.S.; Bielawski, J. Increased ceramide accumulation correlates with downregulation of the autophagy protein ATG-7 in MCF-7 cells sensitized to photodamage. Arch. Biochem. Biophys., 2010, 494(1), 101-105.

[98] Signorelli, P.; Munoz-Olaya, J.M.; Gagliostro, V.; Casas, J.; Ghidoni, R.; Fabrias, G. Dihydroceramide intracellular increase in response to resveratrol treatment mediates autophagy in gastric cancer cells. Cancer Lett., 2009, 282(2), 238-243.

[99] Wang, H.; Maurer, B.J.; Liu, Y.Y.; Wang, E.; Allegood, J.C.; Kelly, S.; Symolon, H.; Liu, Y.; Merrill, A.H., Jr.; GouazeAndersson, V.; Yu, J.Y.; Giuliano, A.E.; Cabot, M.C. N-(4Hydroxyphenyl)retinamide increases dihydroceramide and synergizes with dimethylsphingosine to enhance cancer cell killing. Mol. Cancer Ther., 2008, 7(9), 2967-2976.

[100] Sweeney, E.A.; Sakakura, C.; Shirahama, T.; Masamune, A.; Ohta, H.; Hakomori, S.; Igarashi, Y. Sphingosine and its methylated derivative N,N-dimethylsphingosine (DMS) induce apoptosis in a variety of human cancer cell lines. Int J Cancer, 1996, 66(3), 358366.

[101] Klostergaard, J.; Auzenne, E.; Leroux, E. Characterization of cytotoxicity induced by sphingolipids in multidrug-resistant leukemia cells. Leuk. Res., 1998, 22(11), 1049-1056.

[102] Jarvis, W.D.; Fornari, F.A.; Traylor, R.S.; Martin, H.A.; Kramer, L.B.; Erukulla, R.K.; Bittman, R.; Grant, S. Induction of apoptosis and potentiation of ceramide-mediated cytotoxicity by sphingoid bases in human myeloid leukemia cells. J. Biol. Chem., 1996, 271(14), 8275-8284.

[103] Ohta, H.; Sweeney, E.A.; Masamune, A.; Yatomi, Y.; Hakomori, S.; Igarashi, Y. Induction of apoptosis by sphingosine in human 
leukemic HL-60 cells: a possible endogenous modulator of apoptotic DNA fragmentation occurring during phorbol esterinduced differentiation. Cancer Res., 1995, 55(3), 691-697.

[104] Shirahama, T.; Sweeney, E.A.; Sakakura, C.; Singhal, A.K.; Nishiyama, K.; Akiyama, S.; Hakomori, S.; Igarashi, Y. In vitro and in vivo induction of apoptosis by sphingosine and $\mathrm{N}, \mathrm{N}-$ dimethylsphingosine in human epidermoid carcinoma KB-3-1 and its multidrug-resistant cells. Clin. Cancer Res., 1997, 3(2), 257-264.

[105] Auzenne, E.; Leroux, M.E.; Hu, M.; Pollock, R.E.; Feig, B.; Klostergaard, J. Cytotoxic effects of sphingolipids as single or multi-modality agents on human melanoma and soft tissue sarcoma in vitro. Melanoma Res., 1998, 8(3), 227-239.

[106] Kanno, T.; Nishizaki, T. Sphingosine induces apoptosis in hippocampal neurons and astrocytes by activating caspase-3/-9 via a mitochondrial pathway linked to SDK/14-3-3 Protein/Bax/ Cytochrome c. J. Cell Physiol., 2010.

[107] Hannun, Y.A.; Loomis, C.R.; Merrill, A.H., Jr.; Bell, R.M. Sphingosine inhibition of protein kinase $\mathrm{C}$ activity and of phorbol dibutyrate binding in vitro and in human platelets. J. Biol. Chem., 1986, 261(27), 12604-12609.

[108] Petrusca, D.N.; Gu, Y.; Adamowicz, J.J.; Rush, N.I.; Hubbard, W.C.; Smith, P.A.; Berdyshev, E.V.; Birukov, K.G.; Lee, C.H.; Tuder, R.M.; Twigg, H.L., 3rd; Vandivier, R.W.; Petrache, I. Sphingolipid-mediated Inhibition of Apoptotic Cell Clearance by Alveolar Macrophages. J. Biol. Chem., 2010, 285(51), 4032240332 .

[109] Bonnaud, S.; Niaudet, C.; Legoux, F.; Corre, I.; Delpon, G.; Saulquin, X.; Fuks, Z.; Gaugler, M.H.; Kolesnick, R.; Paris, F. Sphingosine-1-Phosphate Activates the AKT Pathway to Protect Small Intestines from Radiation-Induced Endothelial Apoptosis. Cancer Res. 2010, 70(23), 9905-9915.

[110] Huwiler, A.; Kotelevets, N.; Xin, C.; Pastukhov, O.; Pfeilschifter, J.; Zangemeister-Wittke, U. Loss of sphingosine kinase-1 in carcinoma cells increases formation of reactive oxygen species and sensitivity to doxorubicin-induced DNA damage. Br J Pharmacol, 2011, 162(2), 532-543.

[111] Teicher, B.A. Antiangiogenic agents and targets: A perspective. Biochem. Pharmacol., 2011, 81(1), 6-12.

[112] Schwalm, S.; Pfeilschifter, J.; Huwiler, A. Sphingosine kinase 1 is critically involved in nitric oxide-mediated human endothelial cell migration and tube formation. Br. J. Pharmacol., 2010, 160(7), 1641-1651.

[113] Keul, P.; Lucke, S.; von Wnuck Lipinski, K.; Bode, C.; Graler, M.; Heusch, G.; Levkau, B. Sphingosine-1-Phosphate Receptor 3 Promotes Recruitment of Monocyte/Macrophages in Inflammation and Atherosclerosis. Circ. Res., 2010.

[114] Li, C.; Zheng, S.; You, H.; Liu, X.; Lin, M.; Yang, L.; Li, L. Sphingosine 1-Phosphate (S1P)/S1P Receptors Is Involved in Human Liver Fibrosis by Action on Hepatic Myofibroblasts Motility. J. Hepatol., 2010.

[115] Ishii, M.; Kikuta, J.; Shimazu, Y.; Meier-Schellersheim, M.; Germain, R.N. Chemorepulsion by blood S1P regulates osteoclast precursor mobilization and bone remodeling in vivo. J. Exp. Med., 2010, 207(13), 2793-2798.

[116] Liu, X.; Yue, S.; Li, C.; Yang, L.; You, H.; Li, L. Essential roles of sphingosine 1-phosphate receptor type 1 and 3 in human hepatic stellate cells motility and activation. J. Cell Physiol., 2010.

[117] Lee, C.W.; Choi, J.W.; Chun, J. Neurological S1P signaling as an emerging mechanism of action of oral FTY720 (Fingolimod) in multiple sclerosis. Arch. Pharm. Res., 2010, 33(10), 1567-1574.

[118] Noguchi, K.; Chun, J. Roles for lysophospholipid S1P receptors in multiple sclerosis. Crit. Rev. Biochem. Mol. Biol., 2010.

[119] Hu, P.F.; Chen, Y.; Cai, P.F.; Jiang, L.F.; Wu, L.D. Sphingosine-1phosphate: a potential therapeutic target for rheumatoid arthritis. Mol. Biol. Rep., 2010.

[120] Lai, W.Q.; Wong, W.S.; Leung, B.P. Sphingosine kinase and sphingosine 1-phosphate in asthma. Biosci. Rep., 2011, 31(2), 145150.

[121] Lai, W.Q.; Irwan, A.W.; Goh, H.H.; Melendez, A.J.; McInnes, I.B.; Leung, B.P. Distinct roles of sphingosine kinase 1 and 2 in murine collagen-induced arthritis. J. Immunol., 2009, 183(3), 2097-2103.

[122] Wadgaonkar, R.; Patel, V.; Grinkina, N.; Romano, C.; Liu, J.; Zhao, Y.; Sammani, S.; Garcia, J.G.; Natarajan, V. Differential regulation of sphingosine kinases 1 and 2 in lung injury. Am. J. Physiol. Lung Cell Mol. Physiol., 2009, 296(4), L603-613.

[123] Oskeritzian, C.A.; Alvarez, S.E.; Hait, N.C.; Price, M.M.; Milstien, S.; Spiegel, S. Distinct roles of sphingosine kinases 1 and 2 in human mast-cell functions. Blood, 2008, 111(8), 4193-4200.

[124] Maceyka, M.; Sankala, H.; Hait, N.C.; Le Stunff, H.; Liu, H.; Toman, R.; Collier, C.; Zhang, M.; Satin, L.S.; Merrill, A.H., Jr.; Milstien, S.; Spiegel, S. SphK1 and SphK2, sphingosine kinase isoenzymes with opposing functions in sphingolipid metabolism. $J$. Biol. Chem., 2005, 280(44), 37118-37129.

[125] Hilchie, A.L.; Furlong, S.J.; Sutton, K.; Richardson, A.; Robichaud, M.R.; Giacomantonio, C.A.; Ridgway, N.D.; Hoskin, D.W. Curcumin-induced apoptosis in PC3 prostate carcinoma cells is caspase-independent and involves cellular ceramide accumulation and damage to mitochondria. Nutr. Cancer, 2010, 62(3), 379-389.

[126] Yu, T.; Li, J.; Sun, H. C6 ceramide potentiates curcumin-induced cell death and apoptosis in melanoma cell lines in vitro. Cancer Chemother. Pharmacol., 2010, 66(5), 999-1003.

[127] Olea-Herrero, N.; Vara, D.; Malagarie-Cazenave, S.; Diaz-Laviada, I. The cannabinoid R+ methanandamide induces IL- 6 secretion by prostate cancer PC3 cells. J. Immunotoxicol., 2009, 6(4), 249-256.

[128] Park, M.A.; Mitchell, C.; Zhang, G.; Yacoub, A.; Allegood, J.; Haussinger, D.; Reinehr, R.; Larner, A.; Spiegel, S.; Fisher, P.B.; Voelkel-Johnson, C.; Ogretmen, B.; Grant, S.; Dent, P. Vorinostat and sorafenib increase CD95 activation in gastrointestinal tumor cells through a $\mathrm{Ca}(2+)$-de novo ceramide-PP2A-reactive oxygen species-dependent signaling pathway. Cancer Res., 2010, 70(15), 6313-6324.

[129] Valsecchi, M.; Aureli, M.; Mauri, L.; Illuzzi, G.; Chigorno, V.; Prinetti, A.; Sonnino, S. Sphingolipidomics of A2780 human ovarian carcinoma cells treated with synthetic retinoids. J. Lipid Res., 2010, 51(7), 1832-1840.

[130] Perry, D.K.; Carton, J.; Shah, A.K.; Meredith, F.; Uhlinger, D.J.; Hannun, Y.A. Serine palmitoyltransferase regulates de novo ceramide generation during etoposide-induced apoptosis. J. Biol. Chem., 2000, 275(12), 9078-9084.

[131] Kim, D.S.; Kim, S.H.; Song, J.H.; Chang, Y.T.; Hwang, S.Y.; Kim, T.S. Enhancing effects of ceramide derivatives on 1,25dihydroxyvitamin $\mathrm{D}(3)$-induced differentiation of human HL-60 leukemia cells. Life Sci., 2007, 81(25-26), 1638-1644.

[132] Kim, H.J.; Oh, J.E.; Kim, S.W.; Chun, Y.J.; Kim, M.Y. Ceramide induces p38 MAPK-dependent apoptosis and Bax translocation via inhibition of Akt in HL-60 cells. Cancer Lett, 2008, 260(1-2), 8895.

[133] Meng, A.; Luberto, C.; Meier, P.; Bai, A.; Yang, X.; Hannun, Y.A.; Zhou, D. Sphingomyelin synthase as a potential target for D609induced apoptosis in U937 human monocytic leukemia cells. Exp. Cell Res., 2004, 292(2), 385-392.

[134] Separovic, D.; Mann, K.J.; Oleinick, N.L. Association of ceramide accumulation with photodynamic treatment-induced cell death. Photochem. Photobiol., 1998, 68(1), 101-109.

[135] Takeda, Y.; Tashima, M.; Takahashi, A.; Uchiyama, T.; Okazaki, T. Ceramide generation in nitric oxide-induced apoptosis Activation of magnesium-dependent neutral sphingomyelinase via caspase-3.J. Biol. Chem., 1999, 274(15), 10654-10660.

[136] Bruno, A.P.; Laurent, G.; Averbeck, D.; Demur, C.; Bonnet, J.; Bettaieb, A.; Levade, T.; Jaffrezou, J.P. Lack of ceramide generation in TF-1 human myeloid leukemic cells resistant to ionizing radiation. Cell Death Differ., 1998, 5(2), 172-182.

[137] Senchenkov, A.; Han, T.Y.; Wang, H.; Frankel, A.E.; Kottke, T.J.; Kaufmann, S.H.; Cabot, M.C. Enhanced ceramide generation and induction of apoptosis in human leukemia cells exposed to DT(388)-granulocyte-macrophage colony-stimulating factor (GMCSF), a truncated diphtheria toxin fused to human GM-CSF. Blood, 2001, 98(6), 1927-1934.

[138] Strum, J.C.; Small, G.W.; Pauig, S.B.; Daniel, L.W. 1-beta-DArabinofuranosylcytosine stimulates ceramide and diglyceride formation in HL-60 cells. J. Biol. Chem., 1994, 269(22), 1549315497.

[139] Bonhoure, E.; Lauret, A.; Barnes, D.J.; Martin, C.; Malavaud, B.; Kohama, T.; Melo, J.V.; Cuvillier, O. Sphingosine kinase-1 is a downstream regulator of imatinib-induced apoptosis in chronic myeloid leukemia cells. Leukemia, 2008, 22(5), 971-979. 
[140] Antoon, J.W.; Liu, J.; Ponnapakkam, A.P.; Gestaut, M.M.; Foroozesh, M.; Beckman, B.S. Novel D: -erythro N-octanoyl sphingosine analogs as chemo- and endocrine-resistant breast cancer therapeutics. Cancer Chemother. Pharmacol., 2010, 65(6), 1191-1195.

[141] van Vlerken, L.E.; Duan, Z.; Little, S.R.; Seiden, M.V.; Amiji, M.M. Augmentation of therapeutic efficacy in drug-resistant tumor models using ceramide coadministration in temporal-controlled polymer-blend nanoparticle delivery systems. AAPS J., 2010, 12(2), 171-180.

[142] Qin, J.D.; Weiss, L.; Slavin, S.; Gatt, S.; Dagan, A. Synthetic, nonnatural analogs of ceramide elevate cellular ceramide, inducing apoptotic death to prostate cancer cells and eradicating tumors in mice. Cancer Invest., 2010, 28(5), 535-543.

[143] Kiuchi, M.; Adachi, K.; Kohara, T.; Teshima, K.; Masubuchi, Y.; Mishina, T.; Fujita, T. Synthesis and biological evaluation of $2,2-$ disubstituted 2-aminoethanols: analogues of FTY720. Bioorg. Med. Chem. Lett., 1998, 8(1), 101-106.

[144] Liu, Q.; Zhao, X.; Frissora, F.; Ma, Y.; Santhanam, R.; Jarjoura, D.; Lehman, A.; Perrotti, D.; Chen, C.S.; Dalton, J.T.; Muthusamy, N.; Byrd, J.C. FTY720 demonstrates promising preclinical activity for chronic lymphocytic leukemia and lymphoblastic leukemia/ lymphoma. Blood, 2008, 111(1), 275-284.

[145] Neviani, P.; Santhanam, R.; Oaks, J.J.; Eiring, A.M.; Notari, M.; Blaser, B.W.; Liu, S.; Trotta, R.; Muthusamy, N.; GambacortiPasserini, C.; Druker, B.J.; Cortes, J.; Marcucci, G.; Chen, C.S.; Verrills, N.M.; Roy, D.C.; Caligiuri, M.A.; Bloomfield, C.D.; Byrd, J.C.; Perrotti, D. FTY720, a new alternative for treating blast crisis chronic myelogenous leukemia and Philadelphia chromosome-positive acute lymphocytic leukemia. J. Clin. Invest., 2007, 117(9), 2408-2421.

[146] Roberts, K.G.; Smith, A.M.; McDougall, F.; Carpenter, H.; Horan, M.; Neviani, P.; Powell, J.A.; Thomas, D.; Guthridge, M.A.; Perrotti, D.; Sim, A.T.; Ashman, L.K.; Verrills, N.M. Essential requirement for PP2A inhibition by the oncogenic receptor c-KIT suggests PP2A reactivation as a strategy to treat c-KIT+ cancers. Cancer Res., 2010, 70(13), 5438-5447.

[147] Perrotti, D.; Neviani, P. Protein phosphatase 2A (PP2A), a drugable tumor suppressor in $\mathrm{Ph} 1(+)$ leukemias. Cancer Metastasis Rev., 2008, 27(2), 159-168.

[148] Li, D.; Zhang, Y.; Hu, X.; Cao, W.; Huang, W. Role of extracelluar regulated protein kinases in FTY720-induced apoptosis of leukemia cell lines HL-60 and U937. J. Huazhong Univ. Sci. Technol. Med. Sci., 2004, 24(1), 45-47.

[149] Paugh, S.W.; Payne, S.G.; Barbour, S.E.; Milstien, S.; Spiegel, S. The immunosuppressant FTY720 is phosphorylated by sphingosine kinase type 2. FEBS Lett., 2003, 554(1-2), 189-193.

[150] Billich, A.; Bornancin, F.; Devay, P.; Mechtcheriakova, D.; Urtz, N.; Baumruker, T. Phosphorylation of the immunomodulatory drug FTY720 by sphingosine kinases. J. Biol. Chem., 2003, 278(48), $47408-47415$.

[151] Davis, M.D.; Clemens, J.J.; Macdonald, T.L.; Lynch, K.R. Sphingosine 1-phosphate analogs as receptor antagonists. J. Biol. Chem., 2005, 280(11), 9833-9841.

[152] Sanna, M.G.; Wang, S.K.; Gonzalez-Cabrera, P.J.; Don, A.; Marsolais, D.; Matheu, M.P.; Wei, S.H.; Parker, I.; Jo, E.; Cheng, W.C.; Cahalan, M.D.; Wong, C.H.; Rosen, H. Enhancement of capillary leakage and restoration of lymphocyte egress by a chiral S1P1 antagonist in vivo. Nat. Chem. Biol., 2006, 2(8), 434-441.

[153] Liu, X.; Cheng, J.C.; Turner, L.S.; Elojeimy, S.; Beckham, T.H.; Bielawska, A.; Keane, T.E.; Hannun, Y.A.; Norris, J.S. Acid ceramidase upregulation in prostate cancer: role in tumor development and implications for therapy. Expert Opin. Ther. Targets, 2009, 13(12), 1449-1458.

[154] Gustafsson, K.; Sander, B.; Bielawski, J.; Hannun, Y.A.; Flygare, J. Potentiation of cannabinoid-induced cytotoxicity in mantle cell lymphoma through modulation of ceramide metabolism. Mol. Cancer Res., 2009, 7(7), 1086-1098.

[155] Zeng, L.; Biernacka, K.M.; Holly, J.M.; Jarrett, C.; Morrison, A.A.; Morgan, A.; Winters, Z.E.; Foulstone, E.J.; Shield, J.P.; Perks, C.M. Hyperglycaemia confers resistance to chemotherapy on breast cancer cells: the role of fatty acid synthase. Endocr. Relat. Cancer, 2010, 17(2), 539-551.
[156] Guillermet-Guibert, J.; Davenne, L.; Pchejetski, D.; Saint-Laurent, N.; Brizuela, L.; Guilbeau-Frugier, C.; Delisle, M.B.; Cuvillier, O.; Susini, C.; Bousquet, C. Targeting the sphingolipid metabolism to defeat pancreatic cancer cell resistance to the chemotherapeutic gemcitabine drug. Mol. Cancer Ther., 2009, 8(4), 809-820.

[157] Saddoughi, S.A.; Song, P.; Ogretmen, B. Roles of bioactive sphingolipids in cancer biology and therapeutics. Subcell Biochem., 2008, 49413-440.

[158] Chapman, J.V.; Gouaze-Andersson, V.; Messner, M.C.; Flowers, M.; Karimi, R.; Kester, M.; Barth, B.M.; Liu, X.; Liu, Y.Y.; Giuliano, A.E.; Cabot, M.C. Metabolism of short-chain ceramide by human cancer cells--implications for therapeutic approaches. Biochem. Pharmacol., 2010, 80(3), 308-315.

[159] Cuvillier, O.; Ader, I.; Bouquerel, P.; Brizuela, L.; Malavaud, B.; Mazerolles, C.; Rischmann, P. Activation of sphingosine kinase-1 in cancer: implications for therapeutic targeting. Curr. Mol. Pharmacol., 2010, 3(2), 53-65.

[160] Veldman, R.J.; Koning, G.A.; van Hell, A.; Zerp, S.; Vink, S.R.; Storm, G.; Verheij, M.; van Blitterswijk, W.J. Coformulated N-octanoyl-glucosylceramide improves cellular delivery and cytotoxicity of liposomal doxorubicin. J. Pharmacol. Exp. Ther., 2005, 315(2), 704-710.

[161] Shabbits, J.A.; Mayer, L.D. High ceramide content liposomes with in vivo antitumor activity. Anticancer Res., 2003, 23(5A), 36633669.

[162] van Lummel, M.; van Blitterswijk, W.J.; Vink, S.R.; Veldman, R.J.; van der Valk, M.A.; Schipper, D.; Dicheva, B.M.; Eggermont, A.M.; Ten Hagen, T.L.; Verheij, M.; Koning, G.A. Enriching lipid nanovesicles with short-chain glucosylceramide improves doxorubicin delivery and efficacy in solid tumors. FASEB J., 2010.

[163] Stover, T.C.; Sharma, A.; Robertson, G.P.; Kester, M. Systemic delivery of liposomal short-chain ceramide limits solid tumor growth in murine models of breast adenocarcinoma. Clin. Cancer Res., 2005, 11(9), 3465-3474.

[164] Teitell, M.A.; Mikkola, H.K. Transcriptional activators, repressors, and epigenetic modifiers controlling hematopoietic stem cell development. Pediatr. Res., 2006, 59(4 Pt 2), 33R-39R.

[165] Pieters, R. Infant acute lymphoblastic leukemia: Lessons learned and future directions. Curr Hematol. Malig. Rep., 2009, 4(3), 167174.

[166] Pieters, R.; Carroll, W.L. Biology and treatment of acute lymphoblastic leukemia. Hematol Oncol Clin. North Am., 2010, 24(1), 1-18.

[167] Mandal, C.; Tringali, C.; Mondal, S.; Anastasia, L.; Chandra, S.; Venerando, B. Down regulation of membrane-bound Neu3 constitutes a new potential marker for childhood acute lymphoblastic leukemia and induces apoptosis suppression of neoplastic cells. Int. J. Cancer, 2010, 126(2), 337-349.

[168] Merritt, W.D.; Der-Minassian, V.; Reaman, G.H. Increased GD3 ganglioside in plasma of children with T-cell acute lymphoblastic leukemia. Leukemia, 1994, 8(5), 816-822.

[169] Mukherjee, K.; Chava, A.K.; Mandal, C.; Dey, S.N.; Kniep, B.; Chandra, S. O-acetylation of GD3 prevents its apoptotic effect and promotes survival of lymphoblasts in childhood acute lymphoblastic leukaemia. J. Cell Biochem., 2008, 105(3), 724-734.

[170] O'Donnell, P.H.; Guo, W.X.; Reynolds, C.P.; Maurer, B.J. N-(4hydroxyphenyl)retinamide increases ceramide and is cytotoxic to acute lymphoblastic leukemia cell lines, but not to non-malignant lymphocytes. Leukemia, 2002, 16(5), 902-910.

[171] Reaman, G.H.; Taylor, B.J.; Merritt, W.D. Anti-GD3 monoclonal antibody analysis of childhood T-cell acute lymphoblastic leukemia: detection of a target antigen for antibody-mediated cytolysis. Cancer Res., 1990, 50(1), 202-205.

[172] Fais, F.; Tenca, C.; Cimino, G.; Coletti, V.; Zanardi, S.; Bagnara, D.; Saverino, D.; Zarcone, D.; De Rossi, G.; Ciccone, E.; Grossi, C.E. CD1d expression on B-precursor acute lymphoblastic leukemia subsets with poor prognosis. Leukemia, 2005, 19(4), 551-556.

[173] Kunii, N.; Horiguchi, S.; Motohashi, S.; Yamamoto, H.; Ueno, N.; Yamamoto, S.; Sakurai, D.; Taniguchi, M.; Nakayama, T.; Okamoto, Y. Combination therapy of in vitro-expanded natural killer $\mathrm{T}$ cells and alpha-galactosylceramide-pulsed antigenpresenting cells in patients with recurrent head and neck carcinoma. Cancer Sci., 2009, 100(6), 1092-1098. 
[174] Song, W.; van der Vliet, H.J.; Tai, Y.T.; Prabhala, R.; Wang, R.; Podar, K.; Catley, L.; Shammas, M.A.; Anderson, K.C.; Balk, S.P.; Exley, M.A.; Munshi, N.C. Generation of antitumor invariant natural killer $\mathrm{T}$ cell lines in multiple myeloma and promotion of their functions via lenalidomide: a strategy for immunotherapy. Clin. Cancer Res., 2008, 14(21), 6955-6962.

[175] Stirnemann, K.; Romero, J.F.; Baldi, L.; Robert, B.; Cesson, V.; Besra, G.S.; Zauderer, M.; Wurm, F.; Corradin, G.; Mach, J.P.; Macdonald, H.R.; Donda, A. Sustained activation and tumor targeting of NKT cells using a CD1d-anti-HER2-scFv fusion protein induce antitumor effects in mice. J. Clin. Invest., 2008, 118(3), 994-1005.

[176] Banchet-Cadeddu, A.; Henon, E.; Dauchez, M.; Renault, J.H.; Monneaux, F.; Haudrechy, A. The stimulating adventure of KRN 7000. Org. Biomol. Chem., 2011.

[177] Shiozaki, M.; Tashiro, T.; Koshino, H.; Nakagawa, R.; Inoue, S.; Shigeura, T.; Watarai, H.; Taniguchi, M.; Mori, K. Synthesis and biological activity of ester and ether analogues of alphagalactosylceramide (KRN7000). Carbohydr. Res., 2010, 345(12), 1663-1684.

[178] Veerapen, N.; Reddington, F.; Salio, M.; Cerundolo, V.; Besra, G.S. Synthesis of truncated analogues of the iNKT cell agonist, alpha-galactosyl ceramide (KRN7000), and their biological evaluation. Bioorg. Med. Chem., 2011, 19(1), 221-228.

[179] Michieletti, M.; Bracci, A.; Compostella, F.; De Libero, G.; Mori, L.; Fallarini, S.; Lombardi, G.; Panza, L. Synthesis of alphagalactosyl ceramide (KRN7000) and analogues thereof via a common precursor and their preliminary biological assessment. $J$. Org. Chem., 2008, 73(22), 9192-9195.

[180] Hayakawa, Y.; Rovero, S.; Forni, G.; Smyth, M.J. Alphagalactosylceramide (KRN7000) suppression of chemical- and oncogene-dependent carcinogenesis. Proc. Natl. Acad. Sci. USA, 2003, 100(16), 9464-9469.

[181] Schneiders, F.L.; Scheper, R.J.; von Blomberg, B.M.; Woltman, A.M.; Janssen, H.L.; van den Eertwegh, A.J.; Verheul, H.M.; de Gruijl, T.D.; van der Vliet, H.J. Clinical experience with alphagalactosylceramide (KRN7000) in patients with advanced cancer and chronic hepatitis B/C infection. Clin. Immunol., 2010.

[182] Motohashi, S.; Nagato, K.; Kunii, N.; Yamamoto, H.; Yamasaki, K.; Okita, K.; Hanaoka, H.; Shimizu, N.; Suzuki, M.; Yoshino, I.; Taniguchi, M.; Fujisawa, T.; Nakayama, T. A phase I-II study of alpha-galactosylceramide-pulsed IL-2/GM-CSF-cultured peripheral blood mononuclear cells in patients with advanced and recurrent non-small cell lung cancer. J. Immunol., 2009, 182(4), 2492-2501.

[183] Motohashi, S.; Ishikawa, A.; Ishikawa, E.; Otsuji, M.; Iizasa, T.; Hanaoka, H.; Shimizu, N.; Horiguchi, S.; Okamoto, Y.; Fujii, S.; Taniguchi, M.; Fujisawa, T.; Nakayama, T. A phase I study of in vitro expanded natural killer $\mathrm{T}$ cells in patients with advanced and recurrent non-small cell lung cancer. Clin. Cancer Res., 2006, 12(20 Pt 1), 6079-6086.

[184] Ishikawa, A.; Motohashi, S.; Ishikawa, E.; Fuchida, H.; Higashino, K.; Otsuji, M.; Iizasa, T.; Nakayama, T.; Taniguchi, M.; Fujisawa, T. A phase I study of alpha-galactosylceramide (KRN7000)-pulsed dendritic cells in patients with advanced and recurrent non-small cell lung cancer. Clin. Cancer Res., 2005, 11(5), 1910-1917.

[185] Giaccone, G.; Punt, C.J.; Ando, Y.; Ruijter, R.; Nishi, N.; Peters, M.; von Blomberg, B.M.; Scheper, R.J.; van der Vliet, H.J.; van den Eertwegh, A.J.; Roelvink, M.; Beijnen, J.; Zwierzina, H.; Pinedo, H.M. A phase I study of the natural killer T-cell ligand alpha-galactosylceramide (KRN7000) in patients with solid tumors. Clin. Cancer Res., 2002, 8(12), 3702-3709.

[186] Le Beau, M.M.; Albain, K.S.; Larson, R.A.; Vardiman, J.W.; Davis, E.M.; Blough, R.R.; Golomb, H.M.; Rowley, J.D. Clinical and cytogenetic correlations in 63 patients with therapy-related myelodysplastic syndromes and acute nonlymphocytic leukemia: further evidence for characteristic abnormalities of chromosomes no. 5 and 7. J. Clin. Oncol., 1986, 4(3), 325-345.

[187] Cakir, Z.; Saydam, G.; Sahin, F.; Baran, Y. The roles of bioactive sphingolipids in resveratrol-induced apoptosis in HL60: acute myeloid leukemia cells. J. Cancer Res. Clin. Oncol., 2010.

[188] Dbaibo, G.S.; Kfoury, Y.; Darwiche, N.; Panjarian, S.; Kozhaya, L.; Nasr, R.; Abdallah, M.; Hermine, O.; El-Sabban, M.; de The, H.; Bazarbachi, A. Arsenic trioxide induces accumulation of cytotoxic levels of ceramide in acute promyelocytic leukemia and adult T-cell leukemia/lymphoma cells through de novo ceramide synthesis and inhibition of glucosylceramide synthase activity. Haematologica, 2007, 92(6), 753-762.

[189] Kondo, T.; Matsuda, T.; Kitano, T.; Takahashi, A.; Tashima, M. Ishikura, H.; Umehara, H.; Domae, N.; Uchiyama, T.; Okazaki, T. Role of c-jun expression increased by heat shock- and ceramideactivated caspase-3 in HL-60 cell apoptosis. Possible involvement of ceramide in heat shock-induced apoptosis. J. Biol. Chem., 2000, 275(11), 7668-7676.

[190] Nieda, M.; Nicol, A.; Koezuka, Y.; Kikuchi, A.; Lapteva, N.; Tanaka, Y.; Tokunaga, K.; Suzuki, K.; Kayagaki, N.; Yagita, H.; Hirai, H.; Juji, T. TRAIL expression by activated human CD4(+)V alpha 24NKT cells induces in vitro and in vivo apoptosis of human acute myeloid leukemia cells. Blood, 2001, 97(7), 2067-2074.

[191] Murate, T.; Suzuki, M.; Hattori, M.; Takagi, A.; Kojima, T.; Tanizawa, T.; Asano, H.; Hotta, T.; Saito, H.; Yoshida, S.; TamiyaKoizumi, K. Up-regulation of acid sphingomyelinase during retinoic acid-induced myeloid differentiation of NB4, a human acute promyelocytic leukemia cell line. J. Biol. Chem., 2002, 277(12), 9936-9943.

[192] Nojiri, H.; Kitagawa, S.; Nakamura, M.; Kirito, K.; Enomoto, Y.; Saito, M. Neolacto-series gangliosides induce granulocytic differentiation of human promyelocytic leukemia cell line HL-60. J. Biol. Chem., 1988, 263(16), 7443-7446.

[193] Arai, K.; Taki, T.; Kondo, A.; Matsumoto, M. Ganglioside GM3 as a modulator of differentiation of mouse myeloid leukemia cells (M1-T22). Cell Struct. Funct., 1988, 13(2), 161-169.

[194] Turzanski, J.; Grundy, M.; Shang, S.; Russell, N.; Pallis, M. Pglycoprotein is implicated in the inhibition of ceramide-induced apoptosis in TF-1 acute myeloid leukemia cells by modulation of the glucosylceramide synthase pathway. Exp. Hematol., 2005, 33(1), 62-72.

[195] Pallis, M.; Russell, N. P-glycoprotein plays a drug-effluxindependent role in augmenting cell survival in acute myeloblastic leukemia and is associated with modulation of a sphingomyelinceramide apoptotic pathway. Blood, 2000, 95(9), 2897-2904.

[196] Bonhoure, E.; Pchejetski, D.; Aouali, N.; Morjani, H.; Levade, T.; Kohama, T.; Cuvillier, O. Overcoming MDR-associated chemoresistance in HL-60 acute myeloid leukemia cells by targeting sphingosine kinase-1. Leukemia, 2006, 20(1), 95-102.

[197] Le Scolan, E.; Pchejetski, D.; Banno, Y.; Denis, N.; Mayeux, P.; Vainchenker, W.; Levade, T.; Moreau-Gachelin, F. Overexpression of sphingosine kinase 1 is an oncogenic event in erythroleukemic progression. Blood, 2005, 106(5), 1808-1816.

[198] Reed, J.C. Molecular biology of chronic lymphocytic leukemia. Semin. Oncol., 1998, 25(1), 11-18.

[199] Liu, X.; Ryland, L.; Yang, J.; Liao, A.; Aliaga, C.; Watts, R.; Tan, S.F.; Kaiser, J.; Shanmugavelandy, S.S.; Rogers, A.; Loughran, K.; Petersen, B.; Yuen, J.; Meng, F.; Baab, K.T.; Jarbadan, N.R.; Broeg, K.; Zhang, R.; Liao, J.; Sayers, T.J.; Kester, M.; Loughran, T.P., Jr. Targeting of survivin by nanoliposomal ceramide induces complete remission in a rat model of NK-LGL leukemia. Blood, 2010, 116(20), 4192-4201.

[200] O'Boyle, K.P.; Freeman, K.; Kalisiak, A.; Agregado, A.; Scheinberg, D.A. Patterns of ganglioside expression in B cell neoplasms. Leuk. Lymphoma, 1996, 21(3-4), 255-266.

[201] Pick, J.; Anh-Tuan, N.; Mod, A.; Hollan, S. Ganglioside composition in common acute lymphoblastic leukaemia. Haematologia (Budap), 1986, 19(1), 33-39.

[202] Mone, A.P.; Cheney, C.; Banks, A.L.; Tridandapani, S.; Mehter, N.; Guster, S.; Lin, T.; Eisenbeis, C.F.; Young, D.C.; Byrd, J.C. Alemtuzumab induces caspase-independent cell death in human chronic lymphocytic leukemia cells through a lipid raft-dependent mechanism. Leukemia, 2006, 20(2), 272-279.

[203] Fais, F.; Morabito, F.; Stelitano, C.; Callea, V.; Zanardi, S.; Scudeletti, M.; Varese, P.; Ciccone, E.; Grossi, C.E. CD1d is expressed on B-chronic lymphocytic leukemia cells and mediates alpha-galactosylceramide presentation to natural killer $\mathrm{T}$ lymphocytes. Int. J. Cancer, 2004, 109(3), 402-411.

[204] Tough, I.M.; Court Brown, W.M.; Baikie, A.G.; Buckton, K.E.; Harnden, D.G.; Jacobs, P.A.; King, M.J.; Mc, B.J. Cytogenetic studies in chronic myeloid leukaemia and acute leukaemia associated with monogolism. Lancet, 1961, 1(7174), 411-417. 
[205] Stegmeier, F.; Warmuth, M.; Sellers, W.R.; Dorsch, M. Targeted cancer therapies in the twenty-first century: lessons from imatinib. Clin Pharmacol Ther, 2010, 87(5), 543-552.

[206] Gora-Tybor, J.; Robak, T. Targeted drugs in chronic myeloid leukemia. Curr. Med. Chem., 2008, 15(29), 3036-3051.

[207] Baran, Y.; Salas, A.; Senkal, C.E.; Gunduz, U.; Bielawski, J.; Obeid, L.M.; Ogretmen, B. Alterations of ceramide/sphingosine 1phosphate rheostat involved in the regulation of resistance to imatinib-induced apoptosis in K562 human chronic myeloid leukemia cells. J. Biol. Chem., 2007, 282(15), 10922-10934.

[208] Nica, A.F.; Tsao, C.C.; Watt, J.C.; Jiffar, T.; Kurinna, S.; Jurasz, P.; Konopleva, M.; Andreeff, M.; Radomski, M.W.; Ruvolo, P.P. Ceramide promotes apoptosis in chronic myelogenous leukemiaderived K562 cells by a mechanism involving caspase- 8 and JNK. Cell Cycle, 2008, 7(21), 3362-3370.

[209] McGahon, A.J.; Nishioka, W.K.; Martin, S.J.; Mahboubi, A.; Cotter, T.G.; Green, D.R. Regulation of the Fas apoptotic cell death pathway by Abl. J. Biol. Chem., 1995, 270(38), 22625-22631.

[210] Tringali, C.; Lupo, B.; Cirillo, F.; Papini, N.; Anastasia, L.; Lamorte, G.; Colombi, P.; Bresciani, R.; Monti, E.; Tettamanti, G.; Venerando, B. Silencing of membrane-associated sialidase Neu3 diminishes apoptosis resistance and triggers megakaryocytic differentiation of chronic myeloid leukemic cells K562 through the increase of ganglioside GM3. Cell Death Differ., 2009, 16(1), 164-174.

[211] Nakamura, M.; Kirito, K.; Yamanoi, J.; Wainai, T.; Nojiri, H.; Saito, M. Ganglioside GM3 can induce megakaryocytoid differentiation of human leukemia cell line K562 cells. Cancer Res., 1991, 51(7), 1940-1945.

[212] Tringali, C.; Lupo, B.; Anastasia, L.; Papini, N.; Monti, E.; Bresciani, R.; Tettamanti, G.; Venerando, B. Expression of sialidase Neu2 in leukemic K562 cells induces apoptosis by impairing Bcr-Abl/Src kinases signaling. J. Biol. Chem., 2007, 282(19), 14364-14372.

[213] Cebo, C.; Da Rocha, S.; Wittnebel, S.; Turhan, A.G.; Abdelali, J.; Caillat-Zucman, S.; Bourhis, J.H.; Chouaib, S.; Caignard, A. The decreased susceptibility of Bcr/Abl targets to NK cell-mediated lysis in response to imatinib mesylate involves modulation of NKG2D ligands, GM1 expression, and synapse formation. $J$. Immunol., 2006, 176(2), 864-872.

[214] Macher, B.A.; Buehler, J.; Scudder, P.; Knapp, W.; Feizi, T. A novel carbohydrate, differentiation antigen on fucogangliosides of human myeloid cells recognized by monoclonal antibody VIM-2.J Biol Chem., 1988, 263(21), 10186-10191.

[215] Fukuda, M.N.; Dell, A.; Tiller, P.R.; Varki, A.; Klock, J.C.; Fukuda, M. Structure of a novel sialylated fucosyl lacto-N- norhexaosylceramide isolated from chronic myelogenous leukemia cells. J. Biol. Chem., 1986, 261(5), 2376-2383.

[216] Mondal, S.; Mandal, C.; Sangwan, R.; Chandra, S. Withanolide D induces apoptosis in leukemia by targeting the activation of neutral sphingomyelinase-ceramide cascade mediated by synergistic activation of c-Jun N-terminal kinase and p38 mitogen-activated protein kinase. Mol. Cancer, 2010, 9239.

[217] Modrak, D.E.; Leon, E.; Goldenberg, D.M.; Gold, D.V. Ceramide regulates gemcitabine-induced senescence and apoptosis in human pancreatic cancer cell lines. Mol. Cancer Res., 2009, 7(6), 890-896.

[218] Lin, C.F.; Chen, C.L.; Lin, Y.S. Ceramide in apoptotic signaling and anticancer therapy. Curr. Med. Chem., 2006, 13(14), 1609-1616.

[219] Dumitru, C.A.; Sandalcioglu, I.E.; Wagner, M.; Weller, M.; Gulbins, E. Lysosomal ceramide mediates gemcitabine-induced death of glioma cells. J. Mol. Med., 2009, 87(11), 1123-1132.

[220] Min, J.; Mesika, A.; Sivaguru, M.; Van Veldhoven, P.P.; Alexander, H.; Futerman, A.H.; Alexander, S. (Dihydro)ceramide synthase 1 regulated sensitivity to cisplatin is associated with the activation of $\mathrm{p} 38$ mitogen-activated protein kinase and is abrogated by sphingosine kinase 1. Mol. Cancer Res., 2007, 5(8), 801-812.

[221] Litvak, D.A.; Bilchik, A.J.; Cabot, M.C. Modulators of ceramide metabolism sensitize colorectal cancer cells to chemotherapy: a novel treatment strategy. J. Gastrointest. Surg., 2003, 7(1), 140148; discussion 148

[222] Gouaze-Andersson, V.; Flowers, M.; Karimi, R.; Fabrias, G.; Delgado, A.; Casas, J.; Cabot, M.C. Inhibition of acid ceramidase by a 2-substituted aminoethanol amide synergistically sensitizes prostate cancer cells to $\mathrm{N}$-(4-hydroxyphenyl) retinamide. Prostate, 2010 .

[223] Ji, C.; Yang, B.; Yang, Y.L.; He, S.H.; Miao, D.S.; He, L.; Bi, Z.G. Exogenous cell-permeable C6 ceramide sensitizes multiple cancer cell lines to Doxorubicin-induced apoptosis by promoting AMPK activation and mTORC1 inhibition. Oncogene, 2010, 29(50), 6557-6568.

[224] Senkal, C.E.; Ponnusamy, S.; Rossi, M.J.; Sundararaj, K.; Szulc, Z.; Bielawski, J.; Bielawska, A.; Meyer, M.; Cobanoglu, B.; Koybasi, S.; Sinha, D.; Day, T.A.; Obeid, L.M.; Hannun, Y.A.; Ogretmen, B. Potent antitumor activity of a novel cationic pyridinium-ceramide alone or in combination with gemcitabine against human head and neck squamous cell carcinomas in vitro and in vivo. J. Pharmacol. Exp. Ther., 2006, 317(3), 1188-1199.

[225] Ogretmen, B.; Hannun, Y.A. Biologically active sphingolipids in cancer pathogenesis and treatment. Nat. Rev. Cancer, 2004, 4(8), 604-616.

[226] Oskouian, B.; Saba, J.D. Cancer treatment strategies targeting sphingolipid metabolism. Adv. Exp. Med. Biol., 2010, 688185-205. 